IZA DP No. 8743

Migration and the Demographic Shift

Anzelika Zaiceva

Klaus F. Zimmermann

December 2014

Forschungsinstitut zur Zukunft der Arbeit Institute for the Study of Labor 


\title{
Migration and the Demographic Shift
}

\author{
Anzelika Zaiceva \\ University of Modena and Reggio Emilia \\ and IZA \\ Klaus F. Zimmermann \\ IZA and Bonn University
}

\section{Discussion Paper No. 8743 \\ December 2014}

\author{
IZA \\ P.O. Box 7240 \\ 53072 Bonn \\ Germany \\ Phone: +49-228-3894-0 \\ Fax: +49-228-3894-180 \\ E-mail: iza@iza.org
}

\begin{abstract}
Any opinions expressed here are those of the author(s) and not those of IZA. Research published in this series may include views on policy, but the institute itself takes no institutional policy positions. The IZA research network is committed to the IZA Guiding Principles of Research Integrity.

The Institute for the Study of Labor (IZA) in Bonn is a local and virtual international research center and a place of communication between science, politics and business. IZA is an independent nonprofit organization supported by Deutsche Post Foundation. The center is associated with the University of Bonn and offers a stimulating research environment through its international network, workshops and conferences, data service, project support, research visits and doctoral program. IZA engages in (i) original and internationally competitive research in all fields of labor economics, (ii) development of policy concepts, and (iii) dissemination of research results and concepts to the interested public.
\end{abstract}

IZA Discussion Papers often represent preliminary work and are circulated to encourage discussion. Citation of such a paper should account for its provisional character. A revised version may be available directly from the author. 
IZA Discussion Paper No. 8743

December 2014

\section{ABSTRACT}

\section{Migration and the Demographic Shift}

This chapter connects population aging with international migration. After documenting the trends for both, we review the supply-push and demand-pull determinants of migration, focusing particularly on the role of age and aging. We subsequently discuss the literature concerning the implications of migration in the context of aging for labor markets, health and public budgets including the political economy context. Although immigration is sometimes suggested as a solution for the aging problem, the existing academic literature from different fields is more cautious about its role and potential. While large-scale selective immigration might contribute to alleviating demographic pressures, it is unlikely that immigration will increase to the unrealistically large numbers needed.

JEL Classification: F22, F66, J11, J14, J61, O15

Keywords: $\quad$ aging, migration, demographic pressures, elderly migration, attitudes towards migration, political economy of immigration

Corresponding author:

Klaus F. Zimmermann

IZA

P.O. Box 7240

53072 Bonn

Germany

E-mail: Zimmermann@iza.org

\footnotetext{
"We would like to thank the participants of a workshop at Harvard University as well as Alan Barrett, Deborah Cobb-Clark, Ron Lee, Konstantinos Tatsiramos and Mehmet Tosun for very useful comments and suggestions, Simone Schüller for technical assistance and Vicki Finn for editorial support on earlier drafts of this chapter.
} 


\section{Introduction}

The demographic shift to low mortality and low fertility, as well as its implied population aging and shirking working age population, is one of the most important challenges for a prosperous future of many countries. The expected changes threaten the functionality of labor markets, the adaptability of societies, and the sustainability of pension and healthcare systems and public budgets. The old dependency ratio has already begun to increase, while the working age population has started declining-processes that will continue in the future. Therefore, methods and policies for alleviating the aging challenges have been gaining greater importance for researchers and policymakers. Immigration is sometimes suggested as a solution for the aging problem, assuming that the inflow of young working-age individuals would have a rejuvenating effect on the receiving country's population. Besides the direct demographic effects of contributing to population growth and shifting the age distribution towards a younger age (although the migration of the elderly may also become more important), immigration also tends to increase overall fertility. Migrants typically have higher average fertility than natives, at least at the beginning of their time in the host country, but fertility declines in the next generation. Aging developed countries also need migrants for another reason: The increasing share of older population stimulates higher demand for healthcare and care services in general, and migrants fill the available vacancies in these countries.

However, research also suggests that caution is needed when the overall contribution of immigration is evaluated. First, the increase in immigration needed to compensate for the declining native working age population is expected to be unrealistically large. Second, immigration policies would have to be highly selective, aiming at attracting young and highly skilled migrants, which may exacerbate the brain-drain in developing countries. Third, the successful implementation of pro-immigration policies is difficult and crucially depends on the median voter's attitudes toward immigration. Fourth, there may also be convergence in the demographic and labor market behavior of migrants to that of natives over time, including fertility and retirement decisions. Finally, 
migrants themselves also age in the destination countries. Overall, migration is just one of many effects to be considered when analyzing the results of aging.

This chapter reviews the existing research that brings together population aging and migration identifying gaps in the literature and avenues for future research. We begin in Section 2 by documenting trends in aging and international migration. Section 3 first puts age and migration into a supply-push and demand-pull framework by reviewing studies on the determinants of migration with a particular focus on age and aging issues, then proceeds with a discussion on the mobility of the elderly and demand for eldercare. Section 4 considers implications of migration in the context of aging in labor markets and on public budgets, including within a political economy context. Section 5 discusses migrant health and aging, and Section 6 concludes with implications for policy and suggestions for future research.

\section{Trends in population aging and international migration}

The number of persons aged 60 years or over is projected to grow from 810 million in 2012 to more than 2 billion by 2050, with the number of older persons due to surpass children for the first time in history (UN, 2012a). The old-age support ratio (which measures how many people there are of working age [20-64] relative to the number of retirement age [65+]) is higher in less developed countries than more developed regions, and is projected to further decline in the latter by 2050. By contrast, the old-age dependency ratio (which is a ratio between elderly persons [65+] and the number of persons of working age [generally 15-64]) in the EU27 is projected to double by 2050 (European Commission, 2012). The aging problem is particularly acute in Europe and Japan and less so in the United States (US), where both fertility and immigration are higher. In Italy, for example, the fertility rate has declined to an unprecedented 1.2 children per female, while the share of pensioners is over 70 per 100 workers (Bloom and Sousa-Poza, 2013). Owing to the low fertility rate in most developed regions, net migration has become the main factor of population growth in 
such countries (see Figure 1 for the 28 current EU members). If these trends persist, net migration will solely account for the entire population growth in the developed world by 2050 .

However, measuring international migration is challenging, and making cross-country comparisons is even more complicated due to poor data quality and different definitions (foreignborn vs. foreign nationals, first vs. second generation, stocks vs. flows, etc.). Moreover, migrants have various motives, and as a result, different types of migration exist (work, family reunification, refugees and asylum seekers, retirement and those on holiday trips). For example, labor migrants constitute an important share among all migrants in the United Kingdom (UK), whereas the majority of migrants in the US fall under family reunification, while humanitarian migration represents an important part in Canada, the Netherlands, Norway, and also the UK (OECD, 2007). Finally, often only legal migration is reflected in the official statistics, ${ }^{1}$ and usually only permanent migration is considered when evaluating its impacts, despite much of today's migration being temporary or circular (for a discussion of circular migration, see Constant, Nottmeyer and Zimmermann, 2013).

Despite these measurement problems, it is estimated that the total number of international migrants has increased over the last decades, and reached 232 million persons in 2013, an increase of 57 million persons compared to 2000 (or from 2.8 percent of the world's population to 3.2 percent), 48 percent of whom are females (UN, 2013). At the same time, the number of those over 65 years old has reached 26 million, or 11.1 percent, among all international migrants, ranging from 13 percent of all international migrants in the developed regions to 8 percent in the developing ones, with Europe and Oceania reporting the highest shares: 14 and 15 percent, respectively (ibid.). The majority of international migrants move from less to more developed countries, with their distribution by age suggesting that, relative to the overall population, the largest shares are among the working age (see Figure 2a and 2b). Figure $2 \mathrm{~b}$ also shows that in Canada and Australia (as well

\footnotetext{
${ }^{1}$ It is estimated that illegal migration adds $10-15$ percent to the foreign-born stock in OECD countries (Hatton and Williamson, 2002).
} 
as New Zealand), the proportions of those over 65 is close to those in the working age, and these countries (together with Switzerland) represent regions with the largest shares of migrants over 65 in the overall population, reflecting historical migration patterns and earlier migrations as well as smaller shares of native elderly. Overall, in proportion to the total world population, international migrants over 65 represent 4.5 percent (while those aged 20-64 comprise 4.1 percent), constituting 8.5 percent in the developed regions and 2.1 percent in the developing regions (13.7 and 2.0 percent, respectively) (UN, 2013).

Among the developed countries, the US is the major migrant-receiving country in absolute terms, followed by Germany, which remains the main destination country for migrants in the European Union. Several events in recent history have contributed to the increase in immigration, including the fall of the Berlin Wall and the Soviet Bloc dissolution, wars in former Yugoslavia, the recent EU eastern enlargements and changes in migration and legalization policies, including the recent initiatives to attract skilled migrants. ${ }^{2}$ Although the recent economic downturn has slowed economic migration both to the US and Europe, refugee migration has increased instead due to rising conflicts and wars. Table 1 documents the share of foreign-born together with the old dependency ratio in OECD countries over the last two decades. The largest increases in the shares of foreigners over the last decade have been in Spain and Ireland; in contrast, Israel and Estonia, together with Poland and Russian Federation, have experienced declining shares of the foreign-born population. Japan, Italy and Germany have faced the largest increases in the old dependency ratio since 1990 (Japan was by far the largest), and now represent the countries with the highest old-age dependency ratios.

In developing countries, out-migration efficiently alleviates the problem of the excess supply of labor. Demographic booms, a rapid growth in the cohort of young individuals resulting in greater competition for resources and in the labor market, together with poor national economic

\footnotetext{
${ }^{2}$ For a discussion of historical migration trends in Europe and implications of the eastern enlargements see, among others, Zaiceva and Zimmermann (2008) and Kahanec, Zaiceva and Zimmermann (2010); for a discussion of highskilled migration policies in Europe, see Kahanec and Zimmermann (2011).
} 
performance, are among significant determinants of out-migration. However, many developing countries are also starting to age, owing to declining fertility, increasing life expectancy and the emigration of typically young individuals, consequently facing a potential decline in their working age population in the near future. For example, due to aging and its one-child policies, China is predicted to shift from a large positive natural increase over 1960-2010 to a substantial negative natural increase combined with negative net migration over 2010-2060 (Bruni, 2012). Over 19822005, the mean provincial age rose by approximately 30\% (from just under 21 to nearly 27 years old), while the share of population aged 15-29 has been declining constantly since 1990 onwards (Bodvarsson et al., 2014). Other countries, such as Russia, have experienced low fertility and high mortality rates, accompanied by positive net migration. Furthermore, several new EU member states (Romania, Bulgaria, Latvia and Lithuania) are likely to face serious demographic and economic challenges, accompanied by both low fertility and high out-migration. ${ }^{3}$

In order to forecast future population trends, proposed projections make various assumptions regarding migration; in contrast to birth and death, which are more straightforward to predict, migration represents the most problematic component of population projections (Coleman, 2008; European Commission, 2012). ${ }^{4}$ Accordingly, despite the potential importance of increasing immigration, it is highly unlikely to offset the large declining working age population due to the demographic shift. For example, according to earlier forecasts, net migration to Europe would need to increase fourfold to maintain constant the size of the working-age population (UN, 2006), or almost double according to the most recent projections. However, caution is needed when interpreting these numbers since these projections are subject to great uncertainty and criticism,

\footnotetext{
${ }^{3}$ For an analysis of recent trends in return migration and potential further out-migration in the new EU member states, see Zaiceva and Zimmermann (2014).

${ }^{4}$ For example, it was estimated that an annual net migration of even 2.2 million persons would not be enough to compensate a declining population of -3.4 million persons in the more developed regions by 2050 (UN, 2006, Table 7). Europe will be hit particularly strongly with a natural increase amounting to -3.2 million with net immigration of 0.7 million by 2050, while in North America population growth will be positive ( 0.4 million persons) and net immigration is likely to be larger (1.3 million) by 2050. Contrarily in less-developed regions, net immigration will remain negative in 2050 while there will be a natural increase reaching 37 million persons, most of which will happen in Africa, followed by Asia.
} 
including a controversial "replacement migration" scenario suggested in $2000,{ }^{5}$ followed by several revisions, and an assumption on migration flows declining to zero by 2100. (See, for example, Bruni, 2012, and the references therein for a critical discussion of UN migration projections and suggested alternative scenarios; Coleman, 2008, for a study of demographic effects of migration in Europe; Zlotnik, 2012, for demographic impacts of migration on aging.)

\section{Age and migration: supply and demand framework}

a) Theoretical determinants of migration: supply-push and demand-pull factors

Prior to considering how aging interferes with the migration decision, it is instructive to first briefly discuss the factors affecting the individual choice to migrate (for surveys, see, among others, Massey et al., 1993; Ghatak et al., 1996; Greenwood, 1997 for internal migration; Bauer and Zimmermann, 1999; Borjas, 1999; Bodvarsson and Van den Berg, 2009; for the most recent treatment of the migration decision and migration and ethnicity, see Kennan and Walker, 2013, and Constant and Zimmermann, 2013). Wages and employment differentials between sending and receiving countries are usually considered among the main push and pull factors. The simple neoclassical migration model ${ }^{6}$ postulates that the decision to move depends on the wage differences between the two regions, which may be extended to include the expected rather than the actual wage differential and the probability of finding employment in the destination (Harris and Todaro, 1970). Hence, at the aggregate level, differences in earnings, unemployment rates, costs of living, public goods and public transfers are important determinants of a move.

The microeconomic approach emphasizes that migration is an investment in human capital, underlying the importance of expected returns and costs of migration (Sjaastad, 1962). As in any investment decision, an individual calculates the present discounted value of the expected lifetime

\footnotetext{
${ }^{5}$ According to the UN report, "replacement migration refers to the international migration that would be needed to offset declines in the size of population, the declines in the population of working age, as well as to offset the overall ageing of a population”.

${ }^{6}$ For a more complex dynamic intertemporal model see Kennan and Walker (2013).
} 
earnings stream, i.e. the returns to her human capital, in sending and receiving regions, and only migrates if the returns of net migration costs are higher in the destination. Age plays an important role since the older the individual, the smaller the probability to move, which reflects the smaller expected lifetime gain from moving for older people (see below). Furthermore, the decision to move is also affected by the costs of moving, including not only the monetary costs such as travel expenses and foregone earnings, but also psychological costs arising from the separation from family and friends. Skills are also important, given that moving costs are lower for more skilled individuals, reflecting lower job search costs as well as transferability of human capital. Moreover, a larger geographical distance between the sending and receiving regions will deter migration, reflecting higher migration costs as well as less or lower quality information about more distant labor markets.

Migrant networks existing in the destination region, or diasporas, constitute another relevant factor in the migration decision (Massey, 1990). ${ }^{7}$ The costs of moving are substantially reduced when there are migrants from the same sending country already residing in a particular destination country, since they can provide information about the labor market, housing and other conditions in the host country. Family considerations are also important, and some migrants may not necessarily gain from migration as tied-movers, while migration probability decreases with family size (Sandell, 1977; Mincer, 1978). From another perspective, migration can be a risk-sharing strategy of a household, choosing to send some of its members abroad to diversify risks to its income from asymmetric shocks. Additionally, migration may occur in order to improve the income situation of a household relative to other households, in a so-called relative deprivation approach (Stark and Taylor, 1991).

Overall, migrants may be positively or negatively selected with respect to their characteristics; that is, they may be drawn from the highest or lowest part of the skills distribution in

\footnotetext{
${ }^{7}$ See, among others, Beine et al. (2011a, 2011b), Pedersen et al. (2008) for recent econometric tests with macro data, and Beine et al. (2011c) for a literature review on the impact of migrant networks and relevant methodological issues and Plaza (2013) on the diaspora literature.
} 
the home country (Borjas, 1987, Chiswick, 2000). The Roy model applied by Borjas (1987) suggests that relative inequality between the two countries matters as more (less) skilled individuals move from countries with more (less) equal income distribution to countries with less (more) equal income distribution since payoff to skills is larger in the latter. However, Chiquiar and Hanson (2005) offer an additional case of an intermediate selection and find evidence that Mexican migrants in the US are drawn from the middle of Mexico’s skill distribution.

In order to better understand how age affects the migration decision, let us further rely on a human capital framework and consider a sending country $s$ and a receiving country $r$ with respective wages $w^{s}$ and $w^{r}$. Assume that an individual decides at age 20 whether or not to migrate by comparing the wages that these countries offer. Assuming a retirement age of 65, the present value of her expected lifetime earnings in two locations can be written as:

$$
P V\left(w^{s}\right)=\sum_{a=20}^{65} \frac{w_{a}^{S}}{(1+r)^{a-20}} \quad \text { and } P V\left(w^{r}\right)=\sum_{a=20}^{65} \frac{w_{a}^{r}}{(1+r)^{a-20}}
$$

where $r$ is the discount rate and $a$ is the individual's age. Further assuming the costs of migration $C_{i}$, the individual will move if the returns, net of the costs of movement, are larger in a potential destination region than those in the country of origin:

$$
P V\left(w^{r}\right)-C_{i}>P V\left(w^{s}\right)
$$

A straightforward implication of the human capital theory is that younger individuals will have a higher probability of migrating due to the greater time horizon over which to reap the returns to this investment. Furthermore, the costs of moving, which include not only monetary costs but also the psychic costs of separation from family and friends or information search costs, might be higher for older individuals. Thus, the supply of migrants will be larger at younger ages.

Drawing on Borjas (1987), Chiswick (2000), Hatton (2005) and Clark et al. (2007), the migration equation can be expressed as follows. Assume an individual $i$ with skills $s_{i}$ decides between remaining in source country $s$ and obtaining wage $w_{s}\left(s_{i}\right)$ or moving to a receiving country $r$ and earning wage $w_{r}\left(s_{i}\right)$. The move involves costs that can be individual-specific, such as the 
psychic cost of separation from family and friends $\left(z_{i}\right)$, as well as costs that are common for all individuals, such as ticket fares $(c)$. The probability of an individual moving to country $r$ will depend on the net gain from migration:

$$
\operatorname{Prob}(M=1)=\operatorname{Prob}(V>0)
$$

where $V=w_{r}\left(s_{i}\right)-w_{s}\left(s_{i}\right)-z_{i}-c$.

Assuming that wages and costs are normally distributed with means $\mu_{s}, \mu_{r}$ and $\mu_{z}$, and summing over all individuals, the emigration rate from the source country to the destination country can be expressed as follows:

$$
M=1-\Phi\left[\frac{-\mu_{r}+\mu_{s}+\mu_{z}+c}{\sigma_{V}}\right]
$$

This equation implies that, for a given skill level, the emigration rate will be higher with: a higher mean wage rate in the receiving country, a lower mean wage rate in the sending country, or lower mean individual-specific migration costs and fixed migration costs. This equation can be further extended by adding policy variables such as quotas or skill-specific selective migration policy parameters (Clark et al., 2007; Mayda, 2010).

\section{b) Empirical studies with individual data}

Numerous empirical studies have estimated the individual migration decision, consistently concluding that age has a negative impact on the migration probability (see, among others, Bauer and Zimmermann, 1999 for a review; Zaiceva and Zimmermann, 2008). Table 2 reviews the selected studies and presents coefficients of age estimates. Despite different countries and time periods for which estimates have been carried out as well as different econometric methods, the studies presented in Table 2 overwhelmingly show that age negatively affects the decision to move. When entered non-linearly into the migration equation, it has an inverted U-shaped profile with the maximum migration likelihood manifesting at younger ages, mostly at 20 or 30 years old. 
A host of studies examines determinants of migration intentions rather than the actual migration decision. However, it has to be kept in mind that such intentions do not necessarily transform into actual actions. ${ }^{8}$ These studies arrive at similar conclusions regarding migration determinants as those that employ actual migration data. In particular, younger individuals are found to be more likely to intend to move abroad, consistent with the human capital theory of migration.

Our own analysis of the individual determinants of migration in Europe confirms that older individuals are less likely to move. In the European context, Zaiceva and Zimmermann (2008) analyze intentions to move abroad for individuals from both new and old EU member states before and after the 2004 EU enlargement, and show that age has a similar strong negative effect in both regions. In order to analyze the actual migration decision, we have merged data from the EU Labor Force Survey for 10 new EU member states across 2009 and 2010. The survey contains a question on the current country of work, from which we identify work migrants as those whose current country of work varies from their home country. As explanatory variables, we generated several age dummies, since age is coded into categories in the survey. Table 3 reports the marginal effect from probit regressions for different age brackets. Two facts are worth noting from this table. First, the probability to work in another country decreases with age and is lower for the most elderly individuals. Of course, it also reflects the lowest likelihood of work for these individuals in general, and the results remain unchanged when we control for the labor force status of an individual in column (2). Second, the probability of working abroad is the highest at 20-29 years of age, in line with the aforementioned studies using individual data.

\section{c) Empirical studies with aggregate data}

\footnotetext{
${ }^{8}$ Although several studies find that intentions are correlated with a subsequent move, other researchers claim a substantial forecast error exists (see, for instance, a recent study of van den Berg and Weynandt, 2013, for the case of return migration).
} 
At the aggregate level, demographic factors, in particular the size of the young cohort, are among the key "fundamentals that drive world migration" (Hatton and Williamson, 2002, 2003; Clark et al., 2004). As the authors note, it may affect emigration directly by raising the share of young in the overall population, thus increasing the proportion of individuals with a higher propensity to move, as well as indirectly via labor market effects. Such generational crowding, or being born into a large cohort, increases competition in the labor market and thus acts as a push-factor for emigration. Therefore, the age structure in sending countries reflect an important determinant of migration, and emigration is expected to be larger from countries with population distributions skewed towards younger ages. Similarly, the relative proportion of the young-age population in the receiving countries may also influence immigration into these countries.

As noted above, migration is a forward-looking investment decision, and the present value of migrating is determined by the difference between discounted income streams in destination and source countries, net of discounted migration costs. This net gain from migration will depend on the remaining working period of individual $i$, with larger gains the longer this period is. In other words, the younger the potential migrant, the larger the net gain from migrating and thus the higher the probability of moving. Hence, migration will be affected by the share of young individuals in the source country: the larger it is, the higher emigration will be for a given wage differential, net of costs (Clark et al., 2002). In addition, high fertility (thus a high supply of young labor) and generational crowding, combined with low local labor demand, also stimulates emigration. On the contrary, declining fertility and demographic shifts in the source country will affect the share of young individuals entering the labor market and likely diminish the emigration rate.

Indeed, the increase in Mexico’s population relative to the US has been an important factor affecting Mexican emigration. Population changes were a result of differences in the timing of demographic transitions in these countries: in the US, fertility rates began to fall in the late 1950s, compared to after the 1980s in the case of Mexico (Hanson and McIntosh, 2010). As the Mexican fertility rate is converging to the US level, Hanson and McIntosh (2009) suggest that future 
emigration from Mexico will decline significantly, with the expected emigration rate for labor market entrants in 2030 to be only one-third of the level it was in 2000; this is assuming constant labor demand and leaving aside network effects that seem to attract migrants even with slowing population growth (Hanson and McIntosh, 2010).

Regarding the share of the young population in the source country, some studies find that it significantly influences migration (see Table 4). On the other hand, Clark et al. (2007) find that the demographic variable is not statistically significant in their regression for emigration to the US from 81 countries when using within or between estimators. Hatton and Williamson (2003) report elasticities of emigration out of Africa that are, as they note, comparable to those found in their earlier study for the late $19^{\text {th }}$ century European, and particularly Irish, emigration. In particular, an approach instrumenting the share of young adults by the proportion of the population aged 10-14 five years earlier, suggests that a rise in the share of the African young adult population by 5 percentage points increases net out-migration by 1.3 per thousand. Consistent with these emigration findings, the share of young adults in the receiving countries is negatively correlated with immigration, with the magnitude of the effect implying that a decrease in the receiving country's young adult share by 5 percentage points would increase net immigration rate by 0.9 per thousand of the population (Hatton and Williamson, 2002). There is also a similar effect when including a younger cohort into the analysis (as in Hatton and Williamson, 2011), indicating that a one percentage point increase in the cohort aged 0-14 years in the source country would increase emigration to the US by around 3 percent.

Moreover, projecting migration into the future until 2030 suggests that migration pressure from the developing world to the US will not increase and that the composition of future US immigrants will shift from Hispanic to more African. Decomposing this overall effect, the authors show that the demographic variable has the largest negative impact on future migration for Latin America, Asia, the Middle East and North Africa, offsetting the positive impact of the income gap and leading to the overall negative effect. On the contrary, the demographic pressures are of a much 
smaller magnitude in sub-Saharan Africa, with dominating relative income and education gaps as well as strong network effects, thus leading to the overall large positive impact on future emigration.

Hanson and McIntosh (2010, 2012) employ another approach. The authors measure net bilateral migration rates by year and age cohorts using data on immigrant stocks from destination country censuses divided by the size of the respective birth cohorts from the origin country. Identifying how shocks to young cohorts affect migration over their working lives accounts for dynamic life cycle effects. This approach allows for examining international migration over a long time span, which exploits country-of-origin variation in birth rates (labor supply). However, this comes at the expense of ignoring self-selection issues, given that it requires aggregating across-skill levels. Hanson and McIntosh (2012) show that a 10 percent increase in the relative size of the origin birth cohort leads to a 0.36 percentage point increase in the net migration rate to the US over the course of 10 years; this is similar to the number found using Mexican data (Hanson and McIntosh, 2010), where cross-state, cross-time variation in the timing of the demographic transition was used for identification. In other words, the 52 percent decrease in total fertility rates that occurred in Mexico between 1978 and 2002 would alone cause the fraction of Mexican birth cohorts migrating to the US each decade to drop by almost 2 percentage points. These results are in line with Hatton and Williamson (2011), which predict a future decline in Latin American and Caribbean immigration to the US over the next two decades, along with an increasing share of immigrants from sub-Saharan Africa.

Our own new estimates of immigration to Germany from 212 countries as an illustrative example show that the share of young population in the country of origin has an expected positive effect only before the 2008 crisis and for more developed countries (see Table 5). In the case of immigration to Germany from the rest of the world, the impact of demographic structure in the sending countries is not statistically significant, consistent with Clark et al. (2007). 
What are the implications of the demographic aging in light of the aforementioned theoretical determinants? First, the human capital model implies that the net benefits of migration are lower and the costs of moving are higher for older workers, both due to the shorter time horizon to reap the returns on migration investment, as well as the higher costs of job search, learning and physical move, larger social capital and more origin- or firm-specific human capital. Hence, population aging in the source countries may lead to a decreasing overall migration. Second, although fertility remains higher in many developing regions than in developed ones, it is also declining in many migrant-sending countries. Thus, postponed births and demographic shifts to low fertility in the regions of origin also signify a lower supply of migrant labor.

The overall conclusion from the aforementioned studies is that the demographic structure of the population is an important determinant of migration, and that younger cohorts are generally more likely to move. Generational crowding acts as a push-factor via its direct impact on migration probability and its indirect effects in labor markets. Demographic transitions shape current migration patterns and are likely to influence the future nature of migration. In the US, the composition of migrants is shifting and is predicted to further shift from fewer Mexicans to more Africans or Asians, with an important part of this change attributable to demographic factors. In general, population aging in many migrant-sending countries is likely to lead to a fall in the average migration rate, as older workers are in general less likely to move. Older individuals may face higher costs of moving in terms of weaker health and psychic costs of separating from family and friends. In addition, there may be certain institutional restrictions on the mobility of elderly related to pension transferability, access to health care in new destinations or, as an extreme case, restrictions on mobility such as the Chinese Hukou, which excludes elderly from a priority group for granting a new registration required for accessing free medical assistance in a new destination (Bodvarsson et al., 2014).

Finally, aging may have an additional spillover effect: the mobility of workers of all ages may decrease, as demonstrated in a recent study (Karahan and Rhee, 2014). The authors develop a 
model suggesting that with an increase in the share of older workers with higher moving costs it is more profitable for firms to hire more local workers as older workers accept lower wages. This in turn reduces both in- and out-migration in this state. The authors show that 60 percent of the decline in the US interstate migration is due to population aging, while almost 80 percent of it is attributable to this indirect effect of aging.

On the other hand, however, there may also be an increase in elderly migration as the large baby-boom generation reaches retirement age, due to increased life expectancy and better health. Moreover, migration of old-age care workers may become relatively more important due to the increasing share of the elderly in many countries. Finally, return migration is also likely to happen more frequently at older ages. The next sub-section sheds more light on these issues.

\section{d) Changing migration patterns: mobility of the elderly and demand for elder-care}

The share of population aged 65 and over will increase in the future as the large baby-boom generation cohort approaches retirement age. This is also likely to lead to an increased mobility of the elderly. Indeed, after a declining migration probability from the age of 30 onwards (see previous section), research shows that there is another migration peak around the retirement age. Constant and Massey (2003), analyzing 14 years of longitudinal data on immigrants in Germany, establish that the probability of return migration is larger closer to retirement and that return is also determined by social attachments in Germany and in origin countries. Cobb-Clark and Stillman (2013) derive a theoretical model in which the probability of return migration is maximized at retirement and, consistent with it, estimate a negative relationship between immigrants' retirement status and the return migration rate of their fellow countrymen, thus suggesting that immigrants from countries with higher return migration rates are less likely to be observed as retired in Australia compared to immigrants from countries with lower return migration rates. Yahirun (2009) similarly shows that elderly male migrants in Germany are more likely to return when aged 62 to 74 relative to 51 to 55 . Both studies define return migration as migration abroad given respondents' 
older age. In addition, among elderly men who are naturalized German citizens, those with vocational education, employed full-time, have German-born children, homeowners and also those receiving subsidized housing are less likely to move abroad, whereas those who are married and receive unemployment benefits are more likely to return (emigrate) (Yahirun, 2009).

Factors affecting migration of the elderly differ from the conventional push and pull factors that drive migration for work-related reasons, such as wages and unemployment differentials. ${ }^{9}$ Better climate and other environmental amenities, low costs of living, accessible and affordable health care, low taxes, good service infrastructure and proximity to family and friends are among the main macro-level pull factors of retirement migration, while higher-level education, greater wealth and higher income are related to a higher likelihood of retirement migration at the individual level (Jones, 2008; Sander et al., 2010). However, Dimou and Schaffar (2014) do not find a significant impact of medical care, consumption facilities or cultural amenities on elderly migration within France, while the impact of real estate prices is ambiguous. Elderly migration may also be a response to a reduced income after retirement as a strategy of saving on housing and other consumption costs by moving to less expensive (often non-urban) areas. Employing the European Community Household Panel, Tatsiramos (2006) shows that homeowners above the age of 50 are less likely to move compared to renters, and that older age homeowners mostly move to smaller dwellings. Moreover, a mortgage, retirement, death of a spouse and excessive housing costs are positively correlated with a move in central and northern European countries, but not in southern ones. However, geographic mobility of the "oldest old" in need for care may also be towards the larger cities in order to be closer to relatives working there or to elderly care providers (Sander et al., 2010).

Immigration policies also matter. Family unification migration in the US has turned out to be an important phenomenon in the context of aging. Tienda (2013) shows that as a result of the

\footnotetext{
${ }^{9}$ For a recent review of the existing sociological and economic studies, see, for example, Sander et al. (2010). Jones (2008) discusses migration of the elderly, analyzes its factors and related migration of care specialists in Asian countries; he concludes that both retirement migration and migration of care workers are likely to increase with aging.
} 
1965 Amendments to the Immigration and Nationality Act, there was an increase in late-age immigration for migrants from all regions. Indeed, if in the beginning of 1980s, the share of children (0 to 16 years old) outnumbered the elderly migrants (50 and older) by more than double, after 2005 these shares became roughly equal (around 17 percent). The share of late-age immigrants from Asia increased from around 14 to almost 20 percent over the same period, constituting the largest share among migrants and suggesting that sponsoring parents is significantly higher for Asians than for other immigrants (see also Jasso and Rosenzweig, 1989). On the other hand, countries might seek to attract retirement migrants, who may bring their funds and savings to the destination; explicit policies may be adopted in order to reach this goal, for example specific retirement visas, used in some Asian countries such as the Philippines, Thailand, Indonesia, and Malaysia (Jones, 2008).

Finally, healthcare and elderly care workers may also move in response to an increased demand for such services. Indeed, health professionals, particularly physicians, are overrepresented among the immigrant population in most OECD countries, and the international migration of these professionals is aimed at overcoming short-term or area-specific (often in rural or remote areas) shortages in both developed and developing countries (see Grignon et al., 2013 for a recent review of the studies on determinants and impacts of the migration of health professionals). Population aging constitutes a longer-term rationale for the migration of healthcare workers, although it is likely to change the composition of these migrants from, for example, pediatricians towards more ophthalmologists or chronic disease specialists and even more so towards low-skilled healthcare providers (ibid.). Examples of such policies include Canada’s formal "live-in caregiver program”, which was initially designed for childcare workers yet is increasingly being used for elderly care workers (Grignon et al., 2013), as well as Italy’s reliance on formal and informal elderly care providers, called badanti.

Summarizing this section, age plays an important role in the migration decision and population aging is likely to shape migration patterns. (Zaiceva, 2014, provides an overview of the 
impact of aging for the scale of migration.) The demographic shift in many migrant-sending countries is likely to prompt a fall in the average supply of migrant labor, as older workers are generally less mobile. However, on the other hand, there may be an increase in the relative importance of elderly migration, including return and retirement migration, due to migrant population aging and better health. An increased demand for elder care workers is another likely implication of population aging, and may lead to an even higher mobility of healthcare providers.

\section{Aging and migration: implications for labor markets, welfare and political economy}

a) Migration, labor markets and public finance

While population aging represents a threat to the sustainability of pay-as-you-go pension systems, with the number of taxpayers decreasing while the number of those who draw from the social security system increases, immigration of young labor is sometimes suggested as a means to relieve the strain on public budgets. However, the contribution of immigrants to alleviating the fiscal burden depends on their labor market participation and effects, skill level, as well as their remaining working life span in the host country and lifetime net payments to public budgets. We commence this section by briefly reviewing the effects of migration for labor markets and welfare in the context of population aging, before subsequently discussing the role of migration in studying the effects of aging on public finance.

Labor market impacts of immigration generally depend on migrants’ skills and selection patterns, as well as whether immigrants and natives are substitutes or complements. In a simple model and in the absence of other adjustment mechanisms, those who are substitutes with migrants lose in terms of wages and employment (for example, in the case of low-skilled migrants, lowskilled natives or earlier immigrants), while those whom migrants complement will gain. Typically being younger and often with lower skill levels than natives, immigrants are more likely to be complements to older native workers who have more destination country- and firm-specific human capital. Since an increase in the age of the active population and increased cohort of older workers 
may adversely affect labor market outcomes and productivity (Zimmermann, 1991; Winkelmann and Zimmermann, 1993; Bloom and Sousa-Poza, 2013), immigration may have a rejuvenating effect. Zimmermann (1991) and Winkelmann and Zimmermann (1993) are among the few earlier economic studies to have analyzed the implications of aging for labor markets, namely on unemployment and mobility.

Although not directly considering migration in the model, Zimmermann (1991) suggests that the relatively high immigration of Eastern Germans would not substantially change the aging issue in the West, highlighting a positive impact of relative cohort size and age on unemployment in the short run, with no evidence of higher unemployment in the long run. An increase in the age of the active population might also reduce labor mobility, increase unemployment and adversely affect productivity, thus generating efficiency losses (Winkelmann and Zimmermann, 1993). Furthermore, it is also likely to lead to a mismatch between labor demand and supply due to the reduced mobility of older workers, as well as their inappropriate skills or unwillingness to accept wage cuts. Consequently, immigration might contribute to easing the problems of aging, given that immigrants (in contrast to natives) are more mobile due to positive selection and their job-to-job changes are found to be unrelated to age. However, the authors also find that while being less frequently unemployed than natives at the early stages of their working lives, immigrants are more frequently unemployed in later stages. This suggests that even if migration occurs on a larger scale and might ease problems of aging via reduced average age of the working population and increased flexibility and mobility, it may also incur a cost in terms of more frequent unemployment in later stages of the life cycle. Since immigrants themselves also age, they might adjust their behavior, including job mobility and labor supply, to that of natives. On the other hand, however, immigrants' assimilation into the receiving country's labor market could result in a lower probability of unemployment for migrants who have spent more years in the host country.

Furthermore, a recent study by Borjas (2011) finds that the employment rate of native men in the US falls much faster than that of immigrants as retirement approaches, due to the ten-year 
window during which an immigrant needs to work in the US to qualify for Social Security benefits. Once this ten-year rule is satisfied, the probability of being employed also substantially falls for older immigrants. Moreover, the sizable cohort effect, which suggests the declining relative employment propensity across successive immigrant cohorts of arrival, mirrors the decline in earnings and overall cohort quality documented in the earlier literature (Borjas, 1985). ${ }^{10}$

On the aggregate, researchers conclude that migration is not likely to play a significant role when analyzing the effects of aging, including in terms of growth and development (Bloom and Canning, 2004; Bloom et al., 2010; Bloom et al., 2011). Moreover, the effects of population aging on economic growth are likely to be modest. Generational crowding may influence relative wages and labor supply, but life-cycle behavior is also likely to change, with these behavioral effects (longer working life, higher productivity and labor force participation, higher savings and investment in human capital) counteracting the potential negative consequences of aging (Bloom and Sousa-Poza, 2013). The benefits of such a “demographic dividend” crucially depend on proper policies, including those concerning migration, fertility, more flexible pension arrangements, or encouraging labor force participation. Indeed, a special issue of Labour Economics was recently dedicated entirely to aging and productivity, including an introductory article in which Bloom and Sousa-Poza (2013) emphasize that even if older individuals might be less productive than their younger counterparts, changes in the behavior of both individuals and firms, as well as relevant policies, will counterbalance the declining working age population and shifting age structure.

Regarding fiscal impacts of immigration, numerous papers have investigated immigrants’ contributions to public budgets and their welfare dependency; some have explicitly focused on aging and whether or not immigration can alleviate the demographic burden (see, for example,

\footnotetext{
${ }^{10}$ The effects of population aging on labor markets and its implications for public policy are extensively discussed in Börsch-Supan (2003), taking Germany as an example, while Börsch-Supan (2008) discusses implications for labor, product and capital markets. The author suggests that in addition to increased taxes and contributions, labor productivity will need to increase, hence calling for more and more efficient education and training to speed up human capital formation. In addition, the demand for goods will shift towards more services and products for older individuals, implying, in turn, important changes in employment structure across different sectors of the economy and requiring a substantial increase in labor mobility.
} 
Borsch-Supan, 1994; Felderer, 1994 for early contributions). In general, the role of social security benefits in attracting immigrants and the effect of immigration on public budgets depend on immigrants' attachment to the labor market and on their welfare consumption. The impact remains controversial and varies across countries, studies and gender. While some studies document an existence of a “welfare magnet” (Borjas, 1999), others find essentially no role of social security benefits in attracting immigrants, even within the EU, which has generous social security systems, although some report immigrants relying more on welfare in Northern European countries (see, among others, Barrett and McCarthy, 2008; Kerr and Kerr, 2011; Giulietti and Wahba, 2013). Moreover, despite some evidence that low-skilled migrants are net beneficiaries of the welfare state (Borjas and Trejo, 1991; Borjas, 1999), even if migrants consume public goods such as healthcare and education, young and highly skilled migrants are usually considered net contributors to social security systems. In this context, the immigration of young labor migrants is suggested to alleviate the fiscal burden resulting from aging.

Migration and capital mobility have been typically ignored in the analysis of the demographic transition in developed countries which mainly employed closed economy models (Fehr et. al, 2004). Both partial and general equilibrium frameworks nowadays cover these aspects. One strand of the literature uses the generational accounting approach to calculate the fiscal consequences of immigration. Generational accounting is a dynamic framework as it allows for calculating the net discounted contribution for both immigrants and natives over their lifetimes as well as for future generations. This methodology calculates the present value of the current and future generational accounts and compares their sum with future government consumption and initial net debt. If the sum is smaller than the latter two components, the current fiscal policy is not sustainable.

Incorporating immigration into a generational accounting framework, Auerbach and Oreopoulos (1999) show that immigration in the US reduces the fiscal burden for natives when the entire fiscal balance is shifted to future generations, although the gain is quite small. Bonin et al. 
(2000) find a somewhat larger impact for Germany, namely that increased immigration may help to decrease the fiscal burden for future generations who would face a tax reduction. There is a larger positive impact both with more skilled immigration and with migrants' integration into the labor market. These positive fiscal effects are for two reasons: first, younger migrants are net contributors to public budgets, even after taking into account their additional government consumption; and second, the larger size of the future native-born cohort.

As argued in Bonin et al. (2000), a larger effect for Germany compared to the US is due to more pronounced aging and a smaller share of foreigners residing in Germany. However, also in this case, even huge immigration flows would only partially alleviate the fiscal pressures of aging. Positive net fiscal contribution of migrants for Germany, including over the lifetime, is reported also in Zimmermann and Hinte (2005). Unsurprisingly, net tax contributions are the highest during the period of active labor market participation. Moreover, older migrants, although being net receivers of transfer payments, are much less a burden to public funds than natives of the same age group. The migrant population also has a more favorable demographic structure, with migrants on average being younger than natives and approximately two-thirds belonging to age groups that are net contributors to public funds according to the generational balances. In contrast, the authors find that in Denmark, the fiscal impact is only marginally positive for migrants within the age range 35 to 65, while it is negative for all migrants. Important differences are found between West European and non-West European migrants: while the former's fiscal impact is similar to that of natives, the latter exhibit negative effects across all ages both in the short run and over the lifetime. The results for Denmark may be attributable also to a relatively larger share of refugees among migrants.

Immigrants are found to positively contribute also to the Italian welfare system throughout their working lives, which results in only partially alleviating the fiscal burden on future generations, and the impact is larger when migrants permanently remain in the country (Moscarola, 2003). Positive and significant impact of immigration on intertemporal public finance is found also for Spain (Collado et al., 2004). The overall conclusion from these studies is that immigration alone 
cannot entirely sustain fiscal systems, although selective immigration policies combined with proper pension and fiscal reforms may contribute to alleviating the burden for future generations. However, being a partial equilibrium framework, the generational accounting cannot consider other relevant factors, such as factor prices.

When calculating the net gain of immigrants it is important to account for the costs and eventual contributions of their children. Lee and Miller (1997) in their calculations for the US were the first to recognize and correct the problem inherent in earlier studies using the immigrant household approach: such studies ignored the fact that immigrant children born in the US were included in calculations of costs (i.e. as they were present in a household), but were dropped once they left a household, thus excluding their future tax contributions. The authors also find that the long-term fiscal impacts of immigrants depend on their educational level, age and time spent in the US, with higher educated and young migrants generating substantial net fiscal premia (see also Lee and Miller, 2000 for a revision). Overall, this model is consistent with the generational accounting framework discussed above, when public goods are included into the latter, and also suggest a selective immigration policy.

Another approach has relied on a general equilibrium framework. Storesletten (2000) employs a dynamic equilibrium overlapping generations model and considers the age and skill composition of immigrants in the US. The author shows that if immigration predominantly involves young, legal and highly skilled individuals who pay taxes, the net fiscal effects are likely to be large and positive, even when accounting for the future costs of retirement as well as for family migration with children. However, even without accounting for family and taking the most feasible age range of immigrants (25-49 years old), it would require an 11-fold increase in high-skilled immigration compared to current numbers to offset aging effects. In addition, return migration reduces the discounted contribution of high-skilled immigrants under 50.

Fehr et al. (2004) are also less enthusiastic regarding the role of immigration in alleviating the aging burden. They develop a three-region (US, Japan, Europe) dynamic overlapping 
generations general equilibrium model introducing immigration and capital mobility into it. Their model is similar to Storesletten's (2000), albeit with some important extensions, and the conclusions are similar, namely that the impact of immigration on alleviating the fiscal burden due to aging in the US is negligible but that increasing the number of high-skilled immigrants can be beneficial. The net effect of immigration is negligible due to other offsetting factors such as lower native wages due to immigration and thus lower taxes, as well as immigrants' consumption of public goods and social welfare. Moreover, improving future public budgets would require huge increases in high-skilled immigrants, all of whom would have to come from the developing world, thus exacerbating brain-drain problems.

The positive net fiscal gain of immigration is smaller in the case of a European welfare state, such as Sweden, having a large public sector and generous social security benefits. Storesletten (2003) employs an overlapping generations model and follows Lee and Miller (1997) to compute the net public gain for a new immigrant, including the costs and contributions of future children. He finds a net gain from immigration of young individuals for public budgets, while the immigration of those younger than 10 and older than 50 implies net costs, as does the immigration of an average migrant, as was the case for the US. These results depend crucially on the migrants' expected labor market participation. The larger gain for the US is due to better labor market performance; particularly, the immigrant employment rate is comparable to that of US natives, whereas in Sweden it is substantially lower for immigrants than for natives. In addition, the immigrant-native wage gap is larger in Sweden than in the US, which has implications for taxes and redistribution policies which are more generous in Sweden. However, it should be acknowledged that such partial equilibrium models with fixed behavior may underestimate the cost of immigration. ${ }^{11}$

Finally, a recent study by Docquier and Marchiori (2012) evaluates the macroeconomic and fiscal impacts of migration in the context of demographic aging not only for the receiving but also

\footnotetext{
${ }^{11}$ Indeed, for example, analyzing the impact of low-skilled immigration in a general equilibrium framework, Canova and Ravn (1999) show that although price effects are small, immigration is associated with tax increases required to finance the increased pressure on the welfare system. See also Borjas (1994).
} 
for the sending countries in a unified framework. The authors analyze migration from the Middle East and Northern African (MENA) countries to the EU15. They employ a multiple region dynamic overlapping generations general equilibrium model that features high- and low-skilled individuals and assume permanent migration, equal fertility of migrants and natives as well as the same educational attainment of immigrant and native children. Their analysis shows that, for the EU, increased migration would alleviate the fiscal and economic pressures of aging. However, selecting immigrants leads only to a moderate reduction in tax rates due to the contemporaneous general equilibrium effects of immigration on wages and skill premium as well as on interest rates. Nevertheless, selecting skilled migrants has a strong positive impact on income per capita. Regarding sending countries, increased emigration, especially of the highly skilled, has a strong detrimental impact on tax rates and income per capita, amplifying the economic and fiscal burden of aging. Moreover, a brain-waste scenario when high-skilled migrants are employed in low-skilled occupations in the receiving countries delivers the worst results for both regions. The negative effects of the brain-drain on sending countries are mitigated if there are various positive diaspora externalities (for example, increased trade or investments between the regions) or ex-ante opportunity for enhanced human capital (the so-called brain-gain scenario), and in particular, in the case of increased incentives to invest in human capital in the origin that lead to the overall increase in the home country's educational attainment. The authors emphasize that due to the future aging problems in MENA countries, such selective migration policies should be temporary.

\section{b) Migration, welfare and political economy}

From a political economy perspective, the older the median voter, the more weight pension spending (and thus higher payroll taxes), elder-care and age-dependent public goods will have in the political agenda. Thus, population aging and a higher demand for and lower supply of social security also influence the political economy debate surrounding migration and voting in favor of or against immigration policies (Razin and Sand, 2007). While many studies have analyzed aging in an 
open economy with international capital mobility, a smaller number of studies have incorporated international mobility of labor. As is noted in Tosun (2009), "the choice between labor and capital mobility indeed matters for the analysis of the effects of population aging” (p. 17). Indeed, migrants may also vote and when allowed to vote for fiscal policy, migrant voters will change the political balance between the young and the old in both labor receiving and labor sending countries, affecting in turn countries' growth prospects (Tosun, 2009). Both young workers migrating to regions with a high concentration of elderly and older migrants moving to certain retiree destinations can lead to a political conflict between the two generations. Taking into account that older voters are also more active, an important consequence of population aging (i.e. of an increasing share of overall elderly voters) is increasing pressure on public budgets to spend on pensions, healthcare and other welfare programs benefiting the old. This may come at an expense of educational spending or other social programs that benefit the young, thus leading to a potential conflict between the two generations. In this context, migration of the elderly is particularly important.

In a static model, migration of the low-skilled who benefit from the welfare system has adverse effects on the native young (see, for example, Wildasin, 1994; Razin and Sadka, 1995). Razin and Sadka (1999, 2000) show that migration is Pareto-improving in a dynamic two-period overlapping generations model with a pay-as-you-go pension system and savings. They show that both current low- and high-income as well as young and old natives benefit from (or at least are not harmed by) low-skilled immigration. The equilibrium is pro-migration even in the case of unskilled migrants who are net beneficiaries of welfare; there is no necessary burden of such migration on future generations, given that the current elderly’s gain may also be spread to future generations. In other words, in an everlasting world, the fiscal burden of low-skilled migration may be shifted forward indefinitely. Hence, all generations would vote in favor of migration.

This model was criticized on various grounds, including by the authors themselves. The model does not incorporate factor prices and potential downward pressures on wages induced by 
immigration, although Razin and Sadka (2000) note that in the case of closed economies wages would decline. Moreover, the model assumes that migrants and natives have the same population growth rate as well as preferences and that the skills of migrants' offspring are similarly distributed to those of natives. Indeed, relaxing these assumptions and instead assuming the higher immigrant fertility (compared to natives) and natives being more skilled than migrant offspring (i.e. immigrants' children have less human capital than natives), Krieger (2004) shows that the results are no longer unambiguous. In his model, there is a positive externality on the domestic retirees due to higher total contributions, and an ambiguous one for domestic workers and future generations, which depends on whether the positive fertility effect or the negative skill effect dominates. If the positive fertility effect dominates, labor supply and contributions would both increase now as well as in the next period, thus not only current retirees would gain but so would the current young and future generations. On the other hand, if the negative skills effect dominates, the immigration impact on pension benefits would be negative since an average immigrant's child would contribute less to the pension system than the average native, while both groups would receive the same benefits. The political economy implications subsequently suggest that retirees will always vote in favor of unlimited immigration while young workers in the initial period will only be proimmigration if the positive fertility effect offsets the negative skills effect (keeping wages constant). Even when wages fall, there may be a welfare gain from a positive effect on future pensions which would offset the negative impact on wages if fertility rates of immigrants or skill levels are sufficiently high, calling for selective migration policies, in line with the studies in the previous section.

Several other studies show that immigration may not be beneficial for public finance and could decrease welfare. Leers et al. (2004) introduces heterogenous labor but abstract from capital. Allowing for general equilibrium effects of aging and migration on wages and incorporating mobile and non-mobile labor, the authors suggest that if immigrants constitute a substantial share of mobile labor and if immigrants' fertility declines less than that of natives, mobile labor may become 
redundant, leading to a decrease in its wages and thus to incentives to emigrate. In addition, higher pay-as-you-go taxes induced by aging create additional incentives for emigration by the young. They also demonstrate that if public pensions are endogenous, i.e., if aging leads the elderly to successfully lobby for higher taxes, it may take several generations before a steady state is reached and the initial migration flow may be opposite to the steady state migration. ${ }^{12}$ Aslanyan (2014) challenges the idea that unskilled immigration may sustain the pension system at all and shows that unskilled immigration not only reduces general welfare but may even decrease pension benefits. This effect appears due to a lower level of capital available post immigration, since immigrants will have children that are not matched by any savings. As a result of such capital dilution, postmigration welfare decreases and even gains in pension benefits from migration are offset by the losses in wages. In particular, for the initial young population, the welfare gains are the highest when immigrants are unskilled, while the initial retired population gain from immigration and the gain increases with the migrant's skill level. Applying data to this model, its political economy implications suggest that immigration policies are based on public finances considerations or that gerontocracy prevails - that is, immigration policy is defined by the current old population, and would cause welfare losses for the current young and for future generations.

Interesting strategic implications appear in Razin and Sand (2007), where both immigration and social security policies are determined endogenously by a majority voting process. Assuming that immigrants have a higher population growth rate than natives (i.e. immigration also influences the future dependency ratio), and that they only gain the right to vote in the second period, while the second generation is identical to natives and has an immediate voting right, their overlapping generations model yields the following implications. If there is an open immigration policy, there will be more young workers in the next period who pay taxes and thus pension benefits will

\footnotetext{
12 Not focusing on political economy, Kemnitz (2003, 2008) introduces unemployment into the analysis. Kemnitz (2003) shows that low-skilled immigration increases the unemployment rate and harms low-skilled natives. Although immigration is beneficial to natives' general welfare overall, this gain can be attenuated by the expansion of the pension system. In Kemnitz's (2008) model, immigration benefits the retirees and improves the pension system only if total employment declines due to the fact that with inelastic labor demand any increase in employment reduces the wages used to finance pensions. See also a review of related studies in Aslanyan (2014).
} 
increase. However, too many young immigrants would mean that the median decisive voter in the next period is also young and will vote for no taxes. Note that, at least according to this theoretical model, seniors would prefer more taxes and taxpayers who generate more pension benefits and thus they would vote for more immigrants.

On the other hand, the young prefer no current taxes and their preferences for immigration are driven by the above two opposing effects. Thus, a threshold level of immigration is necessary such that the young voter would chose immigration quotas in order to strategically switch the next period voter from young to old. Such a “demographic switching” strategy means that the young voter would admit only a limited number of immigrants to enter in order to change the decisive voter's identity from young to old (due to a negative native population growth rate and positive immigrant population growth rate) in the next period to maximize the next period's pension benefits. The older voter would again vote for maximum immigration, which (combined with higher immigrant fertility) would lead to a young decisive voter in the next period, and so on. Thus, this process creates a sort of cycle effect with alternative taxation and a positive migration flow.

In an extended model with the next period's capital as an additional variable, another channel of influence is through savings. There can be an additional "demographic steady” strategy of the young, whereby the maximum amount of immigrants is chosen in order to have a young majority in every period. In this case, a “combined strategy” equilibrium would exist, which would incorporate both the "demographic switching” and "demographic steady" strategies. Overall, the model suggests that the older the native-born population, the more likely it is that the immigration policy will be liberalized to sustain a social security system.

However, the above model does not take into account the effects on factor prices, which are addressed in a companion paper by Razin and Sand (2007) that arrives at similar conclusions as those aforementioned: immigration will be favored as long as it helps to sustain the social security system. In addition, the median voter may vote against immigrants who, assuming perfect substitutability between natives and immigrants, would depress his wages. Drawing on the extended 
models of Sand and Razin (2006, 2007, 2009), Razin and Sand (2009) develop a dynamic political economy model with capital and savings, in which the social security system influences the young decisive voter's attitude to become pro-immigration. In their model, the social security system, through using a political economy mechanism, provides an incentive for more liberal migration policies. An empirical analysis by Cohen, Razin and Sadka (2009) confirms the existence of a significant positive correlation between the generosity of the welfare state and the skill composition of migrants. ${ }^{13}$

Calahorrano (2010) develops an overlapping generations model of a representative democracy that accounts for a higher immigrant fertility and distinguishes between different pension regimes. However, in contrast to Sand and Razin (2007), the author includes all groups of voters rather than a median voter. In her model, in each period, the government sets the immigration level to maximize political support from its voters of both generations. Importantly, the immigration level depends on the pension system design. If pension contributions and benefits are set exogenously by the government, equilibrium immigration is lower than in the absence of a pension system. By contrast, it is higher if the pension level is fixed ex-ante to a relatively generous level, since native workers then benefit from sharing the burden of pension contributions with immigrants. Furthermore, in contrast to Sand and Razin's (2007) dynamic median-voter framework, where equilibrium policies are determined either by the young or the old voters' preferences depending on which generation is in the majority, Calahorrano and Lorz's (2011) overlapping generation model captures the gradual shift in the political weight toward the old generation. The shift is a result of population aging, in other words, a decline in population growth. The authors show that a decline in the growth rate of the native population has an expansionary effect on immigration, which may offset the initial decline in population growth.

\footnotetext{
${ }^{13}$ Much of the aforementioned material is synthesized in the book by Razin, Sadka and Suwankiri (2011), which provides an analytical framework for the political economy of migration policy, including the impact of aging.
} 
Overall, the intergenerational conflict between the old and the young as well as the political implications for sharing public resources has attracted substantial interest in both academia and policy (for a survey of related literature, see, for example, Tosun et al., 2012). Incorporating migration into this debate has important implications. A strand of the literature analyzes political economy of education spending and introducing immigration into this model, Tosun et al. (2012) show that preferences for education spending vary across different elderly age groups. The authors use US county-level data to estimate the effect of the net elderly immigration rate (rather than elderly population shares as in earlier studies) on education spending. They argue that the elderly migration variable is more likely to be exogenous as elderly non-movers tend to be older, less wealthy and have grandchildren enrolled in education. Controlling for the share of the elderly in a state and a state's fixed effects, as well as accounting for the reverse causality, endogeneity of the migration variable and spatial interdependence, the authors find a negative and significant effect of elderly net immigration on education spending in a state. Moreover, this effect is heterogeneous for different age groups as it increases after the age group 55-64, peaks at 75-84 and becomes positive and significant for the $85+$ age group.

When migrants are allowed to vote for fiscal policy and accounting for spending on both social security (benefiting the old) and education (benefiting the young), migrant workers will change the political balance of young and elderly voters and spending structure in both migrant receiving and sending countries, leading in turn to important implications for countries' growth. Tosun (2009, 2014) develops a two-region two-period overlapping generations model with fiscal spending on both education and social security, and provides simulations comparing the implications of labor and capital mobility. In his model, in the absence of migration, as a result of population aging, the median voter becomes older (and with lower ability) and prefers lower taxes to finance education spending (since returns from education are lower for low-ability individuals). With immigration, the age distribution of the population would then shift towards the young and the ability of the median voter would rise. Young migrant workers would vote for the education tax, 
thus leading to higher education spending, higher human capital and larger growth in the receiving region. The sending region would lose its young labor, but may still enjoy capital and income growth.

Various model comparisons show interesting implications. Comparing the model with only capital mobility to the one with both capital and labor mobility, the latter produces more favorable results for the developed region (since labor flowing into it offset the adverse consequences of population aging, in particular for human capital accumulation via enhanced education spending), while the model with solely capital mobility produces more favorable results for the developing region as it retains its young labor and voters while benefiting from capital inflows. Nevertheless, the developing region enjoys capital and income growth in both models. Regarding migration policy, in the model with (exogenously given) restricted labor mobility, the receiving region is slightly better off if the restrictions on labor mobility are delayed till 2030 due to a smaller decrease in returns to labor in that region. Finally, if immigrants' voting rights are restricted for a certain period (stimulating the delayed naturalization of immigrants), the receiving region is particularly worse off as a result of both decreased taxes on education with aging in that region as well as decreased human capital, which in turn has detrimental effects on growth prospects. Note, however, that labor is homogenous in this model, suggesting that wages (and consumption) of all natives decrease in the receiving region, while those in the sending region increase. In addition, the model does not account for voting on social security policies. When applied to the Euro-Mediterranean migration and extending the model by introducing a tax on emigrants by a home country (a braindrain type of tax) it is shown that such a tax has a limiting effect on labor migration and a small negative effect on per worker growth while generating substantial benefits for the south Mediterranean sending countries that could be used to enhance human capital (Tosun, 2011).

\section{c) Individual attitudes towards immigrants}


Overall some of the aforementioned studies concluded that selective immigration, especially of the highly skilled, may prove useful for at least partially sustaining public budgets and that immigration of the young may shift the political balance towards this age group, thus inducing policies that benefit the young generation (such as education, which in turn may lead to a higher growth). Despite these findings, liberalizing immigration is difficult, given that policies in democratic societies are determined by voters and their attitudes. An aging population in turn implies that the age distribution of the median voter is shifted towards the older. Would older individuals vote in favor for or against immigration?

The theoretical arguments outlined above suggest that older individuals should be more in favor of (labor) migration. This is because they benefit from the additional contributions of migrants to public budgets and pensions as well as due to the complementarity between young migrants and older natives who, in contrast to young natives, would not face a wage decrease and are likely to benefit also as capital owners. However, the relation with age is more complicated. For example, individuals may care about the future political balance and behave strategically when choosing current immigration levels (Razin and Sand, 2007), or about the design of pension systems with natives benefiting from sharing pension contributions with immigrants in the presence of fixed pension benefits (Calahorrano, 2010). Empirical studies on the determinants of attitudes towards immigration often find a negative or hump-shaped relationship with age (see a review of studies in Calahorrano, 2013; and, for example, Dustmann and Preston, 2007; Facchini and Mayda, 2009, 2012; Bauer et al., 2000 find a positive correlation for both favorable and unfavorable attitudes). This suggests that even if increased immigration could partially relieve the negative impacts of aging, liberalizing immigration might be further complicated by the aging process per se, since the older electorate may be less in favor of it.

Using panel data for Germany over 1999-2010 to investigate the effect of age on individual preferences towards immigration, Calahorrano (2013) argues that these cross-sectional studies are likely to confound age effects with cohort effects. The negative correlation with age may reflect 
either growing aversion to immigration over one's lifecycle or the fact that older cohorts of individuals are less in favor of immigration while having nothing to do with the individual life cycle effect. As in cross-sectional studies, the author finds that immigration is more of a concern among older rather than younger individuals; however, relative to other areas of worry, immigration is of relatively greater concern at young ages and becomes less prominent over the life cycle. Regarding cohort effects, older cohorts were found to be more concerned about immigration than younger generations.

A study by Ivlevs (2012) incorporates macro-level demographic aging factors into the analysis of the attitudes towards immigration. It tests the cross-sectional correlation between local fertility rates and preferences for immigrants in Latvia, a new EU member in which population aging and a declining labor force (due to both dramatically declined births during the 1990s and emigration) are among the most important issues emerging on the policy agenda. In line with predictions from theoretical political economy models, the elderly and those living in municipalities with low birth rates were found to support immigration more, with this effect being stronger among the older population and females. Another study investigates explicit individual opinions about immigration as an effective solution to the population aging problem using the 2006 Eurobarometer data for 27 EU countries (Ceobanu and Koropeckyj-Cox, 2013). The authors show that, in their complete specification, these attitudes are positively related to education, urban residence, the absence of children, as well as GDP per capita, while the correlation with the share of foreigners is negative. No significant correlation was found for the share of population over 65 , fertility rate or population growth rate.

To illustrate the recent situation, we use the Eurobarometer 71.3 dataset from 2009, which contains similar questions regarding the role of migrants in alleviating the aging burden. In addition, the survey comprises other relevant questions on future pensions and sustainability of European social security systems. Figure 4 plots different domains of the attitudes towards immigrants, namely, labor demand (“we need immigrants to work in certain sectors of our economy”), fiscal and 
welfare ("[legal] immigrants contribute more in taxes than they benefit from health and welfare services") as well as aging ("the arrival of immigrants in Europe can be effective in solving the problem of Europe's ageing population”). The figure indicates that the proportion of individuals who agree that immigrants can alleviate the aging problem is below 40 percent in both the old EU15 and new EU member states. This number is substantially lower than the number indicating the labor demand side for the old EU15 members, that is, the share of respondents agreeing with the need for migrant workers in certain sectors (which is more than 50 percent). By contrast, it is much higher than the one reflecting perceptions in the old EU15 member states regarding immigrants' fiscal contributions: only slightly more than 20 percent of respondents agree that immigrants' net contribution to public budgets is positive (the corresponding figure is over 30 percent in the case of legal immigration). Countries with the largest proportion of respondents perceiving immigration as a solution to the aging problem are Spain, Sweden and Finland, while the new EU member states constitute the group least optimistic in this aspect. Moreover, as expected, there is a negative correlation between the attitudes towards immigration-as-a-solution-to-aging and opinions that the welfare system will be too expensive in 2030 (Figure 5), and a positive correlation with the proportion of individuals who are confident about their future pensions (Figure 6).

To summarize this section, the demographic shift brings about changes and challenges for labor markets and public budgets, while the role of migration per se in alleviating these challenges is likely to be marginal. Overall, the literature is skeptical about the contribution of migration, although properly designed selective migration policies, combined with major fiscal reforms, are suggested to ease the fiscal pressures associated with aging. From a political economy perspective, although the elderly may theoretically prefer more labor migrants who would pay taxes and pension contributions, the situation is actually more complex; empirical studies often report a negative or hump-shaped relationship with age, confirming the importance of age in determining individual attitudes towards immigration. 


\section{Migration, aging and health}

The increasing number of immigrants who age in receiving countries suggests the importance of better understanding their health outcomes and demand for healthcare services. An aging immigrant population may impose an additional strain for healthcare systems. There is indeed some evidence suggesting that immigrants may constitute a burden for countries' healthcare, participating more often than natives in healthcare programs such as Medicaid (Borjas and Hilton, 1996), or relying more on employer-sponsored health insurance in the case of welfare cutbacks (Borjas, 2003). On the other hand, more recent studies for the UK and Germany find no significant differences between immigrants and natives in the use of hospital and general practitioner services (Wadsworth, 2012). There is also evidence that (both legal and undocumented) migrants' healthcare consumption is positively affected by their social networks and by the presence of a physician who speaks their language (Deri, 2005; Devillanova, 2008), both of which might be even more important at older ages.

A substantial body of research across different fields examines the health outcomes of immigrants. The main stylized fact documented in this literature is that, at their time of entry, immigrants are on average healthier than the native population, but that this health advantage dissipates with time in the destination country and is often absent for the second generation. ${ }^{14}$ Among the explanations suggested in the literature for the existence of such a "healthy immigrant effect” are: the positive selection on health for migrants (both due to self-selection and selective health-screening policies in the destination country), a negative selection on health for return migrants (out-migration of less healthy migrants back to their countries of origin, a so-called “salmon bias”), and cultural norms and behavior, including the positive impact of migrant networks and neighborhoods. Additionally mere data problems exist, particularly undercounting deaths or

\footnotetext{
${ }^{14}$ However, the healthy immigrant effect is not necessarily relevant for all categories of migrants. For example, refugees and humanitarian migrants may have worse health upon arrival than the native-born population. Moreover, not all studies find an existing healthy immigrant effect. Finally, there is also significant heterogeneity by immigrant source country and ethnicity, conveying that not all immigrant groups necessarily enjoy a health advantage.
} 
emigration of migrants, or problems with disease diagnoses for migrants due to, for example, their less frequent medical visits, at least upon arrival.

For the US, researchers consistently document that health outcomes of Hispanic, particularly Mexican, immigrants are superior or similar to that of white natives, despite their disadvantageous socio-economic situation, a phenomenon referred to as the "Hispanic paradox" (for a review of the literature, see Markides and Eschbach, 2011; Markides and Gerst, 2011). In contrast, AfricanAmerican death rates are higher than those of whites at all ages, except 85 and over. Moreover, life expectancy of immigrants is reported to be longer than that of US-born, with Asian-Pacific Islander and Hispanic immigrants enjoying the highest life expectancy. However, despite lower mortality, several studies report that Hispanic and other immigrants have poorer self-reported health than nonHispanic whites, as well as find increased prevalence of morbidity, disability, diabetes, hypertension or heart diseases among elderly immigrants, attributing the latter, among others, to the increased life expectancy, but also to better diagnosis and management of chronic diseases (Jasso et al., 2004; Markides and Gerst, 2011 and references therein). Thus, despite immigrants arriving with better health, by old age, they (at least most of the Hispanic minorities) seem to experience more health problems than the native population, even accompanied by a lower mortality and higher life expectancy (ibid.).

Caution, however, is needed when interpreting these trends. First, the deterioration of health status across years tabulated from a cross-section of data may reflect the declining cohort health quality rather than the assimilation or aging effects. Second, a proper counterfactual, that is, health status of migrants had they not migrated, is never observed (Jasso et al., 2004). Selectivity in immigration and out-migration is important, and it is crucial that self-selection including health is quite different at young and older ages. Health is part of an individual's human capital and affects his or her decision to move in a number of ways (ibid.). Since health is positively correlated with labor supply and earnings, healthier individuals will experience a larger gain from migration and hence have a higher probability to move. In addition, the larger the costs of moving (e.g. distance), 
the more pronounced a positive selection on health will be. However, at older ages, labor market motives for migration are less important.

Indeed, while migration is primarily for work at younger ages and wage and employment differentials are main factors (see Section 3), migration at older ages may be driven by quite different motives, such as the presence of amenities or lower costs of living, as well as availability of healthcare services or presence of relatives who could take care of seniors in case of bad health (see Section 3). Consistent with the positive health selection, Jasso et al. (2004) report descriptive evidence of a longer life expectancy at age 5 for Asian and Latino immigrants to the US than for stayers in the countries of origin. However, this advantage in life expectancy falls at ages 65, remaining only slightly higher for immigrants, while disappearing for Hispanic elderly in the second generation. In line with this, Halliday and Kimmitt (2008) analyzing internal migration in the US from 1984 to 1993, find that while for men below age 60 deteriorating health reduces mobility, for older men, mobility is higher both at good and bad health (relative to average health). For women, rather than their own health, it is the health of the spouse that matters, with elderly women being more likely to move with a healthy spouse.

Regarding selective return migration, the evidence is more mixed. Some studies find evidence for the existence of a negative selection on health for Hispanic emigrants (for example, Palloni and Arias, 2004). Meanwhile, Abraído-Lanza (1999) find a mortality advantage also for Cuban migrants who could not freely return home, as well as for Puerto Ricans whose deaths in Puerto Rico are recorded in US national statistics, thus casting doubt on the existence of a "salmon bias”. Turra and Elo (2008) directly test the unhealthy return migration of migrants aged 65 and over by comparing mortality of foreign-born and native emigrants from the US to that of immigrants and natives in the US. The authors find evidence for the "salmon bias" hypothesis for Hispanics, namely that mortality is higher among foreign-born social security beneficiaries living abroad than among their counterparts residing in the US, and the effect is larger among recent emigrants. In addition, they also find an existing "salmon bias" for other non-Hispanic white 
immigrants. Despite the existence of unhealthy elderly out-migration, the authors conclude that it is too small to explain a significant part of the Hispanic mortality advantage. Furthermore, the "salmon bias" due to emigration is partially offset by higher mortality of return migrants to the US.

Alternative explanations of superior Hispanics’ health include protective networks, cultural norms and neighborhoods (see Markides and Eschbach, 2011 and the references therein). Economic strain earlier in the life cycle was also suggested to negatively affect health later in life and thus be attributable for a declining health status of immigrants in old ages (Wakabayashi, 2009). Adapting a host country’s unhealthy behavior and eating habits is obviously also important. Fenelon (2012) suggests that smoking behavior explains an important (though incomplete) part of the Hispanic life expectancy advantage, which is diminished for those born in the US who experience heavier smoking, converging to US natives. ${ }^{15}$ Antecol and Bedard (2006) analyze the "unhealthy assimilation” of migrants in the United States, employing the cross-sectional National Health Interview Survey from 1989 to 1996. The authors control for a large array of factors, attempting to also account for cohort effects. They find that immigrant women, although entering the US with a Body Mass Index (BMI) around 2 percentage points lower than that of native-born women, converge completely to American BMIs within the first decade of residence in the US, while the corresponding numbers for men suggest BMIs 5 percentage points lower upon arrival and closing one-third of the gap after 15 years of residence. Moreover, the results for females were driven largely by Hispanic female immigrants, while black immigrants did not converge to their nativeborn counterparts. In addition, Hispanic and white immigrants, but not black, were also found to converge to their respective US-born counterparts in self-reported health status, unfavorable health conditions and activity limitations (although assimilation was slower for the latter two measures).

Regarding elderly migrants, Basu and Insler (2013) confirm the existence of a significant gap in BMIs upon arrival, again using cross-sectional data and controlling for socio-economic factors, smoking habits, health insurance status, language and cohort of arrival. In addition, the

\footnotetext{
${ }^{15}$ Heavier smoking in the US may be due to an income effect (i.e. higher income in the US).
} 
authors find a significant gap in the consumption of fat between immigrants and natives, which is particularly large for the oldest immigrants in the 50 to 69 age group, with these immigrants consuming 20 to 40 percent less fat on average than natives upon arrival. They also report immigrants increasing their consumption of fats over years spent in the US, and even despite their increased physical activity, with the strongest effects seen among the oldest immigrants belonging to the lowest income quartiles. Finally, this dietary change to more fats was found to be a significant factor behind the increased BMI of immigrants, including those in the oldest age group. The authors, however, were not able to account for regional and geographic variation, including local migrant networks that may be an important determinant of ethnic food consumption patterns.

The existence of a significant health advantage for new immigrants and subsequent convergence to the health of natives is also documented for Canada, Australia, the UK and Germany (see, among others, Gee et al., 2004; Chiswick et al., 2006; Kennedy et al., 2006; Biddle et al., 2007; Sander, 2008; Giuntella and Mazzonna, 2014 and the references therein). An interesting channel of health convergence has been suggested in a recent study for Germany. The authors show that convergence in health is faster among those working in more physically demanding jobs. Moreover, immigrants are also found to positively affect the health of natives, particularly blue-collar workers, by improving their working conditions and reducing the average workload as they select themselves into less healthy occupations that require more physical burden (Giuntella and Mazzonna, 2014). Particularly regarding older immigrants, in line with the research for the US, the situation may differ. Available studies report a non-significant health gap or even a health disadvantage faced by older or aging migrants relative to their native counterparts in terms of both physical and mental health. The healthy immigrant effect was found not to be relevant for recent migrants over 65 years old, using Canadian cross-sectional data; rather the opposite, these migrants, at least men, had worse health on average (both self-reported and objective) than the native-born population (Gee et al., 2004; Kobayashi and Prus, 2012). In addition, old-age migrants who immigrated 10 or more years ago were more similar to natives in terms of their health status. 
No significant health differences (neither subjective nor objective) were documented between Canadian immigrants and native-born aged 55 years and older when not disaggregating by the length of stay or migrant origin and migration status (Newbold and Filice, 2006). ${ }^{16}$ Overall, given that middle-aged or older immigrants constitute over one half of the foreign-born adult population in Canada (Gee et al., 2004), these results suggest important implications for healthcare policies in the country. In general, these studies did not distinguish between different countries of origin, nor account for the cohort effects. Recently, the absence of a healthy immigrant effect for immigrants aged 65 and older was confirmed using several cross-sections and controlling for cohorts of arrival in Canada (Deschenes, 2012). Important differences by source region were also found, with European-born seniors being significantly more likely to have a non-life threatening chronic condition and poor self-assessed health than their Canadian-born counterparts; additionally, older Asian migrants were more likely to have an activity limitation but less likely to have a chronic condition (ibid.).

Employing the 2004 wave of the Survey of Health Aging and Retirement in Europe (SHARE), Lanari and Bussini (2012) report findings from eight important immigrant-receiving Western and Northern European countries (Austria, Belgium, Denmark, France, Germany, Sweden, Switzerland and the Netherlands). The results indicate that, for seniors aged 50 years and older, most immigrant groups, ceteris paribus, are more likely to have worse self-reported health and to suffer from depression than native-born. Additionally, the perception of health is found to worsen with the length of stay (although a non-linear pattern was also found). The highest odds of poor health relative to natives were reported for older Eastern European migrants residing in Germany, France and Sweden, while depression was particularly likely again for Eastern Europeans living in France and Sweden as well as for Africans living in the Netherlands and France. Using the same dataset, Ladin and Reinhold (2013) also suggest that aging immigrants face increased odds of

\footnotetext{
${ }^{16}$ One exception regarded the so-called Health Utilities Index, which is an objective measure of health status, with older immigrants experiencing a lower health index, ceteris paribus.
} 
depression, but this comes despite a physical health advantage found by the authors. ${ }^{17}$ However, apart from the disadvantages of a cross-sectional approach, the comparison group in these studies is native-born.

Our tabulations for Germany are generally in line with these studies (see Table 6). While the proportion of those reporting bad or poor health and those diagnosed with severe illness is lower among recent migrants than natives at younger ages, the situation is reversed in the case of selfreported health for those over 60 and even for those over 40 . This proportion is lower for those seniors who stay in Germany for more than 10 years, converging with the level of natives. Interestingly, the share of immigrants aged 60 and older diagnosed with a severe illness is lower for both recent migrants and for those who stay longer than 10 years than it is for natives.

A final observation worth mentioning is that migration itself, being a stressful event, may adversely affect health, especially in the long run when migrants age. Johnson and Taylor (2012) focus on the effect of migration at young ages on mortality at older ages by investigating longdistance moves within the US from three US states (Montana, North Dakota and South Dakota). Instrumenting migration by being born close to a railroad, the authors find that, given survival until age 65 , migration reduces the probability of living to age 75 by 16 percent relative to stayers. Employing data from the Irish Longitudinal Study on Ageing, Barrett and Mosca (2012a,b,c) find that Irish older returnees are more likely to suffer from alcohol problems and social isolation. They also acknowledge a migration endogeneity problem and attempt to correct for it through using an instrumental variables approach. A recent study suggests an existence of a negative causal effect of migration on health outcomes. Gibson et al. (2013) exploit a natural experiment setting comparing successful and unsuccessful lottery applicants of migration from Tonga to New Zealand, which allows them to experimentally estimate a counterfactual outcome for migrants had they stayed. The authors find no evidence of a "healthy migrant effect" and that migration causes significant and persistent increases in blood pressure and incidence of hypertension, which, in turn, is the major

\footnotetext{
${ }^{17}$ Higher depression rates were also documented for older Mexican American immigrants (Gerst et al., 2010).
} 
risk factor of premature mortality. Migration was also found to increase stress and sodium consumption. In contrast, employing the same natural experiment setting, migration was found to improve the overall mental health for Tongan migrants in the short run (Stillman et al., 2009). This finding is in contrast to the view that migration, as a stressful event, may have negative consequences for mental health, as may a potential hardship or discrimination in the receiving country. The results may be attributable to the fact that the study examined a rather specific migrant group (although the authors show that Tongan migrants are similar in many characteristics to an average work migrant from a developing county), focused on a relatively young population (aged 15 to 48 ) and looked at only the very short-run effect (roughly one year after migrating), while such negative effects for mental health may manifest themselves later in life.

To sum up, despite the overall healthy immigrant effect documented in the literature, the health outcomes for older migrants are less unambiguous. Some recent available studies, mentioned in Section 5, suggest the absence of such an effect and even, in some cases, a worse health status of newly arrived senior immigrants compared to their native-born counterparts, which in turn highlights the importance of different motives for migration later in life (see Section 3). In addition, aging migrants may also experience a health disadvantage due to, for example, assimilation to less healthy habits and diets. Finally migration itself may cause a negative impact on health. On the other hand, negative selection on health for older return migrants may also take place. Finally, there is evidence for welfare states such as the UK and Germany suggesting that migrants do not disproportionally use more hospital and general practitioner services. The net effect depends on the scale of aging migrants in the receiving countries, the magnitude of later-life migration and return migration, as well as the health status of migrants. This in turn has important implications for healthcare policies. 


\section{Conclusions and policy implications}

The demographic shift to low fertility and low mortality and implied population aging represents one of the most important challenges to societies in modern times. In this chapter we have discussed how the interplay between international migration and population aging could impact labor markets, the political economy and healthcare systems in order to explain implications for future immigration policy and public budgets.

Demographic transitions are currently shaping migration patterns and will likely continue to influence the nature of migration in the future. A population's demographic structure is a prominent migration determinant since younger cohorts are generally more mobile. Moreover, generational crowding in sending countries acts as a push factor via its direct impact on migration probability and its indirect effects on labor markets. In general, population aging in many migrant-sending countries is likely to lead to a fall in the average migration rate, given that older workers are generally less likely to move (at least not for work purposes but possibly for consumption). However, there may also be an increase in elderly migration, including return migration, due to increased life expectancy and better health as the large baby-boom generation reaches retirement age. Moreover, the migration of health specialists and elderly care workers may become relatively more important due to the increasing share of the old-age population in many countries.

Regarding the implications of immigration for labor markets and public budgets in the context of aging, existing research suggests that its role is likely to be small overall. In order to sustainability contribute to pension systems and to ease the demographic burden, migration would have to increase by unrealistically large numbers. Even if migration occurred on a larger scale and reduced the average age of the working population, as well as increased flexibility and mobility, it would also possibly incur costs in terms of more frequent unemployment at later life-cycle stages, or pension costs as migrants’ retirement decisions converge to those of natives.

The net effect of immigration for public budgets is also likely to be small due to other offsetting factors, for example, lower native wages due to immigration and thus lower taxes, as well 
as immigrants' consumption of public goods and social welfare. In addition, research has also shown that improving future public budgets would require huge increases in high-skilled immigration; these immigrants would have to come from the developing world, consequently exacerbating existing brain-drain challenges.

Finally, from a political economy perspective, the aging median voter implies more preferences for pension spending and thus higher payroll taxes and voting in favor of more labor migration. In practice, however, individual attitudes towards immigration are often found to be negatively correlated with age or to follow a hump-shaped profile, suggesting a more complicated relationship between age and preferences for immigration. Nevertheless there is also some evidence that natives, and particularly the elderly, living in municipalities with low birth rates are more in favor of immigration, which supports the political economy models.

Although immigration has been suggested as a solution to population aging, it remains a controversial topic with substantial room for further research. On the supply side, population age structure has been incorporated as a demographic determinant into migration decision models; nonetheless further evidence is needed for more countries, including the impact for migrant-sending regions as well as those of elderly migration and return migration. On the demand side, we must gain a better understanding of labor market needs and immigration effects in the context of population aging and a shrinking working age population. Do migrants complement native elderly workers? What are the redistributive effects of immigration in an aging society? Are elderly migrants similar to natives in terms of labor market and retirement behavior? What are interregional and international mobility patterns of elderly migrants and the implied changes in the demand for goods and services in the destination regions? What are the implications of higher demand for and increasing mobility of healthcare and elderly care specialists? From a political economy perspective, are aging societies more pro-immigrant? What are the impacts for healthcare systems in the receiving (and sending) countries as an increasing number of migrants age? Finally, what are 
the future policy challenges handling return migrants' retirement benefits and international pensions? Studies concerning these topics are only beginning to emerge.

Overall, in terms of policy implications, immigration is sometimes suggested as a solution to the aging issue. However, the existing academic literature from different fields is more cautious regarding its actual role and potential. Although selective immigration policies have been argued to possibly contribute to alleviate demographic pressures, it is unlikely that immigration will increase to the unrealistic extent which would be needed. Moreover, the immigration of young and highly skilled from developing countries could exacerbate existing brain-drain problems. It would be necessary to combine selective and effectively managed migration polices with other, probably more straightforward, policies such as proper fiscal and pension reforms, policies aimed at increasing fertility or labor force productivity (through, for example, providing continuous training and re-training), as well as those aimed at increasing the labor force participation of marginal groups, such as women and the elderly (see, among others, Bloom and Sousa-Poza, 2013).

Finally, some authors suggest that temporary and circular migration may constitute a better policy option in dealing with the demographic transition in the developed world (Bodvarsson and Van den Berg, 2009). It should be noted, however, that return migration may also decrease the discounted contribution of high-skilled middle-aged immigrants (Storesletten, 2000). Nevertheless, temporary or circular migration is an example of a triple-win situation in which both receiving and sending countries as well as migrants themselves benefit, which may have a rejuvenating effect on aging societies (Constant, Nottmeyer and Zimmermann, 2013). 


\section{References}

Abraído-Lanza, A. F., B. P. Dohrenwend, D. S. Ng-Mak, and B. Turner (1999). The Latino Mortality Paradox: A Test of the 'Salmon Bias' and Healthy Migrant Hypotheses. American Journal of Public Health, 89, 1543-1548.

Agesa, R. U. (2001). Migration and the Urban to Rural Earnings Difference: A Sample Selection Approach. Economic Development and Cultural Change, 49 (4), 847-865.

Antecol, H. and K. Bedard (2006). Unhealthy Assimilation: Why Do Immigrants Converge to American Health Status Levels? Demography, 43 (2), 337-360.

Aslanyan, G. (2014). The Migration Challenge for PAYG. Journal of Population Economics, 27, 1023-1038.

Auerbach, A. J. and P. Oreopoulos (1999). Analyzing the Fiscal Impact of U.S. Immigration, American Economic Review 89, 176-180.

Barrett, A. and Y. McCarthy (2008). Immigrants and Welfare Programmes: Exploring the Interactions between Immigrant Characteristics, Immigrant Welfare Dependence and Welfare Policy. Oxford Review of Economic Policy, 24 (3), 543-560.

Basu, S. and M. Insler (2013). Diet or Exercise? Evidence from Body Mass Index of U.S. Immigrants. Mimeo.

Barrett, A. and I. Mosca (2012a). Social Isolation, Loneliness and Return Migration: Evidence from Older Irish Adults. IZA Discussion Paper No. 6331.

Barrett, A. and I. Mosca (2012b). The Psychic Costs of Migration: Evidence from Irish Return Migrants. IZA Discussion Paper No. 6324.

Barrett, A. and I. Mosca (2012c). Exploring the Early-life Causes and Later-life Consequences of Migration through a Longitudinal Study on Ageing. IZA Discussion Paper No. 6878.

Bauer, T. K. and K. F. Zimmermann (1999). Assessment of Possible Migration Pressure and its Labour Market Impact Following EU Enlargement to Central and Eastern Europe. 
Study for the Department for Education and Employment of the United Kingdom, IZA Report No. 3, IZA, Bonn, Germany.

Bauer, T., M. Lofstrom, and K. F. Zimmermann (2000). Immigration Policy, Assimilation of Immigrants, and Natives’ Sentiments Towards Immigrants: Evidence from 12 OECD Countries. Swedish Economic Policy Review 7, 11-53.

Beine, M., F. Docquier, and C. Özden (2011a). Diasporas. Journal of Development Economics, 95 (1), 30-41

Beine, M., F. Docquier, and C. Özden (2011b). Dissecting Network Externalities in International Migration. CESifo Working Paper Series 3333, CESifo Group Munich.

Beine, M., F. Docquier, and C. Özden (2011c). Diaspora Effects in International Migration: Key Questions and Methodological Issues. Policy Research Working Paper Series 5721, The World Bank.

Belot, M. and S. Ederveen (2012). Cultural Barriers in Migration Between OECD Countries. Journal of Population Economics, 25, 1077-1105.

Bertocchi, G. and C. Strozzi (2008). International Migration and the Role of Institutions. Public Choice, 137 (1), 81-102.

Biddle, N., S. Kennedy, and J. T. McDonald (2007). Health Assimilation Patterns Among Australian Immigrants. The Economic Record, 83 (260), 16-30.

Bloom, D. E., A. Boersch-Supan , P. McGee, and A. Seike (2011). Population Aging: Facts, Challenges, and Responses. PGDA Working Paper No. 71, Harvard School of Public Health.

Bloom, D. E. and D. Canning (2004). Global Demographic Change: Dimensions and Economic Significance. NBER Working Paper 10817.

Bloom, D. E., D. Canning, and G. Fink (2010). Implications of Population Ageing for Economic Growth. Oxford Review of Economic Policy, 26 (4), 583-612. 
Bloom, D. E. and A. Sousa-Poza (2013). Aging and Productivity: Introduction. Labour Economics, 22 (Special Issue), 1-4.Bodvarsson, Ö. B., J. W. Hou, and K. Shen (2014). Aging and Migration in a Transition Economy: The Case of China. IZA Discussion Paper No. 8351.

Bodvarsson, Ö. B. and H. Van den Berg (2009). The Economics of Immigration - Theory and Policy. Springer-Verlag, Berlin, Heidelberg.

Bonin, H., Raffelhüschen, B., and Walliser, J. (2000), Can Immigration Alleviate the Demographic Burden? FinanzArchiv 57, 1-21.

Borjas, G. J. (2011). Social Security Eligibility and the Labor Supply of Older Immigrants. Industrial and Labor Relations Review, 64 (3), 485-501.

Borjas, G. J. (2003). Welfare Reform, Labor Supply, and Health Insurance in the Immigrant Population. Journal of Health Economics, 22 (6), 933-958.

Borjas, G. J. (1999). The Economic Analysis of Immigration. In: Ashenfelter, O.C. and D. Card (Eds). Handbook of Labor Economics, 1st Edn, Vol 3, Ch. 28. Elsevier, pp. 1697-1760.

Borjas, G. J. (1994). The Economics of Immigration. Journal of Economic Literature, Vol. XXXII, $1667-1717$.

Borjas, G. J. (1987). Self-Selection and the Earnings of Immigrants. American Economic Review, 77 (4), 531-553.

Borjas, G. J. (1985). Assimilation, Changes in Cohort Quality, and the Earnings of Immigrants. Journal of Labor Economics, 3 (4), 463-489.

Borjas, G. J. and L. Hilton (1996). Immigration and the Welfare State: Immigrant Participation in Means-Tested Entitlement Programs. The Quarterly Journal of Economics, 111 (2), 575-604.

Borjas, G. J. and S. J. Trejo (1991). Immigrant Participation in the Welfare System. Industrial and Labor Relations Review, 44 (2), 195-211. 
Börsch-Supan, A. H. (2008). The Impact of Global Aging on Labor, Product, and Capital Markets. Population and Development Review, 34, Population Aging, Human Capital Accumulation, and Productivity Growth, 52-77.

Börsch-Supan, A. H. (2003). Labor Market Effects of Population Aging. LABOUR, 17 (Special Issue), 5-44.

Böheim, R. and M. P. Taylor (2002). Tied Down or Room to Move? Investigating the Relationships between Housing Tenure, Employment Status and Residential Mobility in Britain. Scottish Journal of Political Economy, 49 (4), 369-392.

Bruni, M. (2012). Migrations and Demographic Projections: A New Methodology to Jointly Build Labor Market and Demographic Scenarios. GENUS, LXVIII (3), 1-26.

Calahorrano, L. (2013). Population Aging and Individual Attitudes Toward Immigration: Disentangling Age, Cohort and Time Effects. Review of International Economics, 21, 342-353.

Calahorrano, L. (2010). Aging and Immigration Policy in a Representative Democracy. MAGKS Joint Discussion Paper Series, Discussion Paper No. 18-2010 Marburg University.

Calahorrano, L. and O. Lorz (2011). Aging, Factor Returns, and Immigration Policy. Scottish Journal of Political Economy, 58 (5), 589-606.

Canova, F. and M. Ravn (2000). The Macroeconomic Effects of German Unification: Real Adjustments and the Welfare State. Review of Economic Dynamics, 3 (3), 423-460.

Ceobanu, A. M. and T. Koropeckyj-Cox (2013). Should International Migration Be Encouraged to Offset Population Aging? A Cross-Country Analysis of Public Attitudes in Europe. Population Research and Policy Review, 32, 261-284.

Chiquiar, D. and G. H. Hanson (2005). International Migration, Self-Selection, and the Distribution of Wages: Evidence from Mexico and the United States. Journal of Political Economy, 113 (2), 239-281. 
Chiswick B. R. (2000) Are Immigrants Favorably Self-selected? An Economic Analysis. In: Brettell, C. D. and J. F. Hollifield (Eds.) Migration Theory: Talking Across Disciplines. Routledge, New York.

Chiswick, B. R., Y. L. Lee, and P. W. Miller (2006). Immigrant Selection Systems and Immigrant Health. Contemporary Economic Policy, 26 (4), 555-578.

Clark, X., T. J. Hatton, and J. G. Williamson (2007). Explaining US Immigration, 1971-1998. The Review of Economics and Statistics, 89 (2), 359-373.

Clark, X., T. J. Hatton, and J. G. Williamson (2004). What Explains Emigration Out of Latin America? World Development, 32 (11), 1871-1890.

Clark, X., T. J. Hatton, and J. G. Williamson (2002). Where Do U.S. Immigrants Come From, and Why? NBER Working Papers 8998, National Bureau of Economic Research.

Cobb-Clark, D. A. and S. Stillman (2013). Return Migration and the Age Profile of Retirement among Immigrants. IZA Journal of Migration, 2 (20).

Cohen, A., A. Razin, and E. Sadka (2009). The Skill Composition of Migration and the Generosity of the Welfare State. NBER Working Paper No. 14738.

Coleman, D. (2008). The Demographic Effects of International Migration in Europe. Oxford Review of Economic Policy, 24 (3), 452-476.

Collado, D., I. I. Iturbe-Ormaetxe, and G. Valera (2004). Quantifying the Impact of Immigration in the Spanish Welfare State. International Tax and Public Finance, 11(3), 335-353.

Constant, A. F. and D. S. Massey (2003). Self-Selection, Earnings, and Out-Migration: A Longitudinal Study of Immigrants to Germany. Journal of Population Economics, 16 (4), 631-653.

Constant, A. F., O. Nottmeyer and K. F. Zimmermann (2013). The Economics of Circular Migration. In: Constant, A. F. and K. F. Zimmermann (Eds.), International Handbook on the Economics of Migration, Edward Elgar, Cheltenham, UK, and Northampton, USA, Ch. 3, pp. 55-74. 
Constant, A. F. and K. F. Zimmermann (2013). Migration and Ethnicity: An Introduction. In: Constant, A.F. and K. F. Zimmermann (Eds.), International Handbook on the Economics of Migration, Edward Elgar, Cheltenham, UK, and Northampton, USA, Ch. 1, pp. 13-35.

Deri, C. (2005). Social Networks and Health Service Utilization. Journal of Health Economics, 24 (6), 1076-1107.

Deschênes, C. (2012). Is the Healthy Immigrant Effect Present for Older Age Groups? Major paper presented to the Department of Economics of the University of Ottawa in partial fulfillment of the requirements of the M.A. Degree, Ottawa, Ontario, April 2012.

Devillanova, C. (2008). Social Networks, Information and Health Care Utilization: Evidence from Undocumented Immigrants in Milan. Journal of Health Economics, 27 (2), 265-286.

Dimou, M. and A. Schaffar (2014). Elderly Migration in France: 1999-2011. Mimeo.

Docquier, F. and L. Marchiori (2012). The Impact of MENA-to-EU Migration in the Context of Demographic Change. Journal of Pension Economics and Finance, 11 (2), 243-284.

Dustmann, C. and I. P. Preston (2007). Racial and Economic Factors in Attitudes to Immigration. The B.E. Journal of Economic Analysis \& Policy, 7 (1), 1-41.

European Commission (2012). The 2012 Ageing Report. Economic and Budgetary Projections for the 27 EU Member States (2010-2060). European Economy 2/2012. DG for Economic and Financial Affairs.

Facchini, G. and A. M. Mayda (2012). Individual Attitudes Towards Skilled Migration: An Empirical Analysis Across Countries. The World Economy, 35 (2), 183-196.

Facchini, G. and A. M. Mayda (2009). Does the Welfare State Affect Individual Attitudes Toward Immigrants? Evidence Across Countries. The Review of Economics and Statistics, 91 (2), 295-314.

Fehr, H., S. Jokisch, and L. J. Kotlikoff (2004). The Role of Immigration in Dealing with the Developed World’s Demographic Transition. FinanzArchiv, 60 (3), 296-324. 
Felderer, B. (1994). Can Immigration Policy Help to Stabilize Social Security Systems? In: Giersch, H. (Ed.) Economic Aspects of International Migration, Berlin: Springer, pp. 197-226.

Fenelon, A. (2012). Revisiting the Hispanic Paradox in the United States: The Role of Smoking. Population Studies Center and Department of Sociology, University of Pennsylvania, mimeo.

Gee, E. M., K. M. Kobayashi, and S. G. Prus (2004). Examining the Healthy Immigrant Effect in Mid- to Later Life: Findings from the Canadian Community Health Survey. Canadian Journal of Aging, 23 (Supplement): S55-S63.

Gerst, K., M. Al-Ghatrif, H. Beard, R. Samper-Ternent, and K. S. Markides (2010). Higher Depressive Symptomatology Among Older Community-dwelling Mexican Americans: The Impact of Immigration. Aging and Mental Health, 14 (3), 347-354.

Ghatak, S., P. Levine, and S. Price (1996). Migration Theories and Evidence: An Assessment. Journal of Economic Surveys, 10 (2), 159-198.

Gibson, J., S. Stillman, D. McKenzie, and H. Rohorua (2013). Natural Experiment Evidence on the Effect of Migration on Blood Pressure and Hypertension. Health Economics, 22 (6), $655-672$.

Giulietti, C. and J. Wahba (2013). Welfare Migration. In: Constant, A. F. and K. F. Zimmermann (Eds.), International Handbook on the Economics of Migration, Edward Elgar, Cheltenham, UK, and Northampton, USA, Ch. 26, pp. 489-504.

Giuntella, O. and F. Mazzonna (2014). Do Immigrants Bring Good Health? IZA Discussion Paper No. 8073.

Greenwood, M. J. (1997). Internal Migration in Developed Countries. In: Rosenzweig, M. R. and O. Stark (Eds.), Handbook of Population and Family Economics, Elsevier, Vol. 1, Part B, Ch. 12, pp. 647-720.

Grignon, M., Y. Owusu and A. Sweetman (2013). The International Migration of Health Professionals. In: Constant, A. F. and K. F. Zimmermann (Eds.), International 
Handbook on the Economics of Migration, Edward Elgar, Cheltenham, UK, and Northampton, USA, Ch. 4, pp. 75-97.

Halliday, T. J. and M. Kimmitt (2008). Selective Migration and Health. Working Papers 200720, University of Hawaii at Manoa, Department of Economics.Hanson, G. H. and C. McIntosh (2012). Birth Rates and Border Crossings: Latin American Migration to the US, Canada, Spain and the UK. Economic Journal, 122 (June), 707-726.

Hanson, G. H. and C. McIntosh (2010). The Great Mexican Emigration. The Review of Economics and Statistics, 92 (4), 798-810.

Hanson, G. H. and C. McIntosh (2009). The Demography of Mexican Migration to the United States. American Economic Review, Papers \& Proceedings, 99 (2), 22-27.

Harris, J. R. and M. P. Todaro (1970). Migration, Unemployment and Development: A Two-Sector Analysis. American Economic Review, 60 (1), 126-142.

Hatton, T. J. (2005). Explaining Trends in UK Immigration. Journal of Population Economics, 18, 719-740. Hatton, T. J. and J. G. Williamson (2011). Are Third World Emigration Forces Abating? World Development, 39 (1), 20-32.

Hatton, T. J. and J. G. Williamson (2009). Vanishing Third World Emigrants? NBER Working Paper No. 14785.

Hatton, T. J. and J. G. Williamson (2003). Demographic and Economic Pressure on Emigration out of Africa. Scandinavian Journal of Economics, 105 (3), 465-486.

Hatton, T. J. and J. G. Williamson (2002). What Fundamentals Drive World Migration? NBER Working Paper No. 9159. Hunt, J. (2006). Staunching Emigration from East Germany: Age and the Determinants of Migration. Journal of the European Economic Association, 4 (5), 1014-1037.

Hunt, J. C. and J. B. Kau (1985). Migration and Wage Growth: A Human Capital Approach. Southern Economic Journal, 51 (3), 697-710. 
Ivlevs, A. (2012). Ageing, Local Birth Rates and Attitudes Towards Immigration: Evidence from a Transition Economy. Regional Studies, 46 (7), 947-959.

Jasso, G. and M. R. Rosenzweig (1989). Sponsors, Sponsorship Rates and the Immigration Multiplier. International Migration Review, 23 (4), 856-888.

Jasso, G., D. S. Massey, M.R. Rosenzweig and J. P. Smith (2004). Immigrant Health - Selectivity and Acculturation. IFS Working Paper No. 04/23. Institute for Fiscal Studies, London, UK.

Johnson, J. E. and E. J. Taylor (2012). Does Moving Kill? The Effect of Migration on Older-Age Mortality. Mimeo.

Jones, G. W. (2008). Population Ageing in Asia and Its Implications for Mobility. Population Ageing, 1, 31-49.

Kahanec, M. and K. F. Zimmermann (2011). High-Skilled Immigration Policy in Europe. In: Chiswick, B. R. (Ed.), High Skilled Immigration in a Global Labor Market, Washington DC, The AEI Press, 264-314.

Kahanec, M., A. Zaiceva and K. F. Zimmermann (2010). Lessons from Migration after EU Enlargement. In: Kahanec, M. and K. F. Zimmermann (Eds.), EU Labor Markets after Post-Enlargement Migration, Springer: Berlin, et al., 3-45.

Karahan, F. and S. Rhee (2014). Population Aging, Migration Spillovers, and the Decline in Interstate Migration. Mimeo.

Kemnitz, A. (2008). Can Immigrant Employment Alleviate the Demographic Burden? The Role of Union Centralization. Economics Letters, 99 (1), 123-126.

Kemnitz, A. (2003). Immigration, Unemployment and Pensions. The Scandinavian Journal of Economics, 105 (1), 31-48.

Kennan, J. and J. R. Walker (2013). Modeling Individual Migration Decisions. In: Constant, A. F. and K. F. Zimmermann (Eds.), International Handbook on the Economics of Migration, Edward Elgar, Cheltenham, UK, and Northampton, USA, Ch. 2, pp. 39-54. 
Kennedy, S., J. T. McDonald and N. Biddle (2006). The Healthy Immigrant Effect and Immigrant Selection: Evidence from Four Countries. SEDAP Research Paper No. 164, Canada.

Kerr, S. P. and W. R. Kerr (2011). Economic Impacts of Immigration: A Survey. NBER Working Paper No. 16736.

Kobayashi, K. M. and S. G. Prus (2012). Examining the Gender, Ethnicity, and Age Dimensions of the Healthy Immigrant Effect: Implications for Health Care Policy. International Journal for Equity in Health 2012, 11 (8).

Kohls, M. (2010). Selection, Social Status or Data Artifact - What Determines the Mortality of Migrants in Germany? In: Salzmann, T., B. Edmonston and J. Raymer (Eds.), Demographic Aspects of Migration. VS Verlag / Springer, pp. 153-177.

Krieger, T. (2004). Fertility Rates and Skill Distribution in Razin and Sadka's Migration-pension Model: A Note. Journal of Population Economics, 17, 177-182.

Ladin, K. and S. Reinhold (2013). Mental Health of Aging Immigrants and Native-Born Men Across 11 European Countries. Journals of Gerontology, Series B: Psychological Sciences and Social Sciences, 68 (2), 298-309.

Lanari, D. and O. Bussini (2012). International Migration and Health Inequalities in Later Life. Ageing and Society, 32 (06), 935-962.

Liebig, T. and A. Sousa-Poza (2006). The Influence of Taxes on Migration: Evidence from Switzerland. Cambridge Journal of Economics, 30, 235-252. Lee, R. and T. Miller (2000). Immigration, Social Security and Broader Fiscal Impacts. The American Economic Review, 90 (2), Papers and Proceedings, 350-354.

Lee, R. and T. Miller (1997). The Future Fiscal Impacts of Current Immigrants. In: Smith, J. and B. Edmonston (Eds), The New Americans, Washington DC, National Academy Press, 297-362.

Leers, T., L. Meijdam, and H. A. A. Verbon (2004). Ageing, Migration and Endogenous Public Pensions. Journal of Public Economics, 88, 131-159. 
Markides, K. S. and K. Eschbach (2011). Hispanic Paradox in Adult Mortality in the United States. In: Rogers, R. G. and E. M. Crimmins (Eds.), International Handbook of Adult Mortality, International Handbooks of Population, Springer, Ch. 11, pp. 227-240.

Markides, K. S. and K. Gerst (2011). Immigration, Aging, and Health in the United States. In: Settersten, Jr., R. A. and J. L. Angel (Eds.) Handbook of Sociology of Aging, Handbooks of Sociology and Social Research, Springer, Ch. 7, pp. 103-116.

Massey, D. S. (1990). Social Structure, Household Strategies, and the Cumulative Causation of Migration. Population Index, 56, 1-26.

Massey, D. S., J. Arango, G. Hugo, A. Kouaouci, A. Pellegrino, and J. E. Taylor (1993). Theories of International Migration: A Review and Appraisal. Population and Development Review, 19 (3), 431-466.

Massey, D. S. and A. E. Brown (2011). New Migration Stream Between Mexico and Canada. Migraciones Internacionales, 6 (1), 119-144.

Mayda, A. M. (2010). International Migration: A Panel Data Analysis of the Determinants of Bilateral Flows. Journal of Population Economics, 23, 1249-1274.

Mincer, J. (1978). Family Migration Decisions. Journal of Political Economy, 86 (5), 749-773.

Moscarola, F. C. (2003). Immigration Flows and the Sustainability of the Italian Welfare State. Politica Economica, 1, 63-90.

Newbold, K. B and J. K. Filice (2006). Health Status of Older Immigrants to Canada. Canadian Journal of Aging / La Revue canadienne du vieillissement, 25 (3), 305-319.

OECD (2007). International Migration Outlook: SOPEMI 2007.

Palloni, A. and E. Arias (2004). Paradox Lost: Explaining the Hispanic Adult Mortality Advantage. Demography, 41 (3), 385-415.

Pedersen, P. J., M. Pytlikova, and N. Smith (2008). Selection and Network Effects-Migration Flows into OECD Countries 1990-2000. European Economic Review 52, 1160-1186. 
Plaza, S. (2013). Diaspora Resources and Policies. In: Constant, A. F. and K. F. Zimmermann (Eds.), International Handbook on the Economics of Migration, Edward Elgar, Cheltenham, UK, and Northampton, USA, Ch. 27, pp. 505-529. Razin, A. and E. Sadka (2000). Unskilled Migration: A Burden or a Boon for the Welfare State? Scandinavian Journal of Economics, 102 (3), 463-479.

Razin, A. and E. Sadka (1999). Migration and Pension with International Capital Mobility. Journal of Public Economics, 74 (1), 141-150.

Razin, A. and E. Sadka (1995). Resisting Migration: Wage Rigidity and Income Distribution. American Economic Review, Papers and Proceedings, 85 (2).

Razin, A., E. Sadka, and B. Suwankiri (2011). Migration and the Welfare State. Political-Economy Policy Formation. The MIT Press, Cambridge, Massachusetts.

Razin, A. and E. Sand (2009). Migration-Regime Liberalization and Social Security: PoliticalEconomy Effect. NBER Working Paper No. 15013.

Razin, A. and E. Sand (2007). The Role of Immigration in Sustaining the Social Security System: A Political Economy Approach. CEPR Discussion Paper No. 6302.Sand, E. and A. Razin (2007). The Political-Economy Positive Role of the Social Security System in Sustaining Immigration (But Not Vice Versa). NBER Working Paper No. 13598.

Sand, E. and A. Razin (2006). Immigration and the Survival of Social Security: A Political Economy Model. NBER Working Paper No. 12800.

Sandell, S. H. (1977). Women and the Economics of Family Migration. The Review of Economics and Statistics, 59 (4), 406-414.

Sander, M. (2008). Changes in Immigrants' Body Mass Index with their Duration of residence in Germany. SOEP papers on Multidisciplinary Panel Data Research No. 122, DIW Berlin.

Sander, N., V. Skirbekk, and K. C. Samir, and E. Lundevaller (2010). Prospects for Later-Life Migration in Urban Europe. PLUREL Project. 
Sjaastad, L. A. (1962). The Costs and Returns of Human Migration. Journal of Political Economy 70 (Supplement): 80-93.

Stark, O. and J. E. Taylor (1991). Migration Incentives, Migration Types: The Role of Relative Deprivation. The Economic Journal, 101, 1163-1178.

Stillman, S., D. McKenzie, and J. Gibson (2009). Migration and Mental Health: Evidence from a Natural Experiment. Journal of Health Economics, 28, 677-687.

Storesletten, K. (2003). Fiscal Implications of Immigration - A Net Present Value Calculation. Scandinavian Journal of Economics, 105 (3), 487-506.

Storesletten, K. (2000). Sustaining Fiscal Policy through Immigration. Journal of Political Economy 108, 300-323.Tatsiramos, K. (2006). Residential Mobility and Housing Adjustment of Older Households in Europe. IZA Discussion Paper No. 2435.

Tienda, M. (2013). Mutiplying Diversity: Family Unification and the Regional Origins of Late-Age Immigrants, 1981-2009. Mimeo. Tosun, M. S. (2014). Political Economy of Asymmetric Aging, Migration and Fiscal Policy. Paper presented at the 11th IZA Annual Migration Meeting ( $\left.\mathrm{AM}^{2}\right)$, Bonn.

Tosun, M. S. (2011). Demographic Divide and Labor Migration in the Euro-Mediterranean Region. IZA Discussion Paper No. 6188.

Tosun, M. S. (2009). Global Aging and Fiscal Policy with International Labor Mobility: A Political Economy Perspective. IZA Discussion Paper No. 4166.

Tosun, M. S., C. R. Williamson, and P. Yakovlev (2012). Elderly Migration and Education Spending: Intergenerational Conflict Revisited. Public Budgeting and Finance, 32 (2), 25-39.

Turra, C. M. and I. T. Elo (2008). The Impact of Salmon Bias on the Hispanic Mortality Advantage: New Evidence from Social Security Data. Population Research and Policy Review, 27 (5), 515-530. United Nations (2013). Trends in International Migrant Stock: The 2013 Revision. The Age and Sex of Migrants. 
United Nations (2012). Population Ageing and Development. UN Department of Economic and Social Affairs, Population Division. Available at: www.unpopulation.org

United Nations (2006). World Population Monitoring, Focusing on International Migration and Development. Report of the Secretary-General. Commission on Population and Development. E/CN.9/2006/3.Vadean, F. P. and M. Piracha (2009). Circular Migration or Permanent Return: What Determines Different Forms of Migration? University of Kent, Department of Economics Discussion Paper No. KDPE 09/12.

van den Berg, G. and M. A. Weynandt (2012). Explaining Differences between the Expected and Actual Duration until Return Migration: Economic Changes. SOEP papers on Multidisciplinary Panel Data Research 497, DIW Berlin, The German Socio-Economic Panel (SOEP).

Wadsworth, J. (2012). Musn't Grumble: Immigration, Health and Health Service Use in the UK and Germany. IZA Discussion Paper No. 6838.

Wakabayashi, C. (2009). Effects of Immigration and Age on Health for Older People in the United States. Journal of Applied Gerontology, 20, 1-23.

Wildasin, D. E. (1994). Income Redistribution and Migration. Canadian Journal of Economics, 27 (3), 637-656.

Winkelmann, R. and K. F. Zimmermann (1993). Ageing, Migration and Labour Mobility. In: Johnson, P. and K. F. Zimmermann (Eds.) Labour Markets in an Ageing Europe, CEPR, Cambridge University Press, Ch. 10, pp. 255-283.

Yahirun, J. J. (2009). Take Me “Home”: Determinants of Return Migration Among Germany’s Elderly Immigrants. California Center for Population Research, University of California Los Angeles. On-Line Working Paper Series, Working Paper No. CCPR-2009-019.

Yashiv, E. and N. Levy (2009). The Determinants of Immigration to Israel. The Pinhas Sapir Center for Development, Tel Aviv University, Discussion Paper No. 6-2009. 
Zaiceva, A. (2014). Migration and Aging: Implications for the Migration Scale. IZA World of Labor._Zaiceva, A. and K. F. Zimmermann (2014). Returning Home at Times of Trouble? Return Migration of EU Enlargement Migrants during the Crisis. Forthcoming in: Kahanec, M., and K. F. Zimmermann (Eds.) Migration and the Great Recession: Adjustments in the Labour Market of an Enlarged European Community, Edward Elgar, 2014.

Zaiceva, A. and K. F. Zimmermann (2008). Scale, Diversity, and Determinants of Labour Migration in Europe. Oxford Review of Economic Policy, 24 (3), 428-452.

Zimmermann, K. F. (1991). Ageing and the Labor Market. Age Structure, Cohort Size and Unemployment. Journal of Population Economics, 4, 177-200.

Zimmermann, K. F and H. Hinte (2005). Zuwanderung und Arbeitsmarkt. Deutschland und Dänemark im Vergleich, Springer Verlag Berlin Heidelberg. Ch. 6, pp. 175-220.

Zlotnik, H. (2012). International Migration and Population Ageing. In: Beard, J. R., S. Biggs, D. E. Bloom, L. P. Fried, P. Hogan, A. Kalache, and S. J. Olshansky (Eds.), Global Population Ageing: Peril or Promise, Geneva: World Economic Forum, 2011, Ch. 20, pp. 97-102. 
Table 1: Stock of foreign population and the old dependency ratio in OECD countries and the Russian Federation, 1990-2010

\begin{tabular}{|c|c|c|c|c|c|c|}
\hline \multirow[b]{3}{*}{ Australia } & \multicolumn{3}{|c|}{ Share of foreign born, \% } & \multicolumn{2}{|c|}{ Old dependency ratio,\% } & \multirow[b]{2}{*}{2010} \\
\hline & 1990 & 2000 & 2010 & 1990 & 2000 & \\
\hline & 23.0 & 23.0 & 26.5 & 16.6 & 18.6 & 20.0 \\
\hline Austria & 5.9 & 10.4 & 15.7 & 22.4 & 22.9 & 26.1 \\
\hline Belgium & 9.1 & 10.3 & 15.0 & 22.3 & 25.6 & 26.0 \\
\hline Canada & 17.4 & 18.1 & 19.9 & 16.9 & 18.5 & 18.5 \\
\hline Chile & & 1.2 & 2.2 & 9.8 & 11.3 & 13.1 \\
\hline Czech Republic & & 4.2 & 6.3 & 18.9 & 19.8 & 21.9 \\
\hline Denmark & 3.1 & 5.8 & 7.7 & 23.1 & 22.2 & 25.3 \\
\hline Estonia & & 18.4 & 15.9 & 17.6 & 22.5 & 25.2 \\
\hline Finland & 0.5 & 2.6 & 4.6 & 21.3 & 22.3 & 26.1 \\
\hline France & 6.3 & 7.4 & 11.6 & 21.3 & 24.5 & 26.0 \\
\hline Germany & 8.4 & 12.5 & 13.0 & 23.2 & 28.8 & 31.8 \\
\hline Greece & & 10.3 & 7.3 & 20.5 & 25.0 & 28.7 \\
\hline Hungary & 2.8 & 2.9 & 4.5 & 21.0 & 22.1 & 24.3 \\
\hline Iceland & & 6.4 & 10.9 & 16.5 & 17.8 & 18.1 \\
\hline Ireland & 2.3 & 8.7 & 17.3 & 17.6 & 16.4 & 17.3 \\
\hline Israel & & 32.2 & 24.5 & 15.2 & 15.9 & 15.9 \\
\hline Italy & 1.4 & 2.5 & 8.9 & 21.3 & 26.1 & 30.4 \\
\hline Japan & 0.9 & & & 17.3 & 25.5 & 36.1 \\
\hline Korea & 0.1 & & & 7.4 & 10.1 & 15.2 \\
\hline Luxembourg & 29.4 & 33.2 & 40.9 & 19.5 & 20.7 & 20.4 \\
\hline Mexico & & 0.5 & 0.9 & 7.3 & 7.6 & 9.0 \\
\hline Netherlands & 4.6 & 10.1 & 11.2 & 18.6 & 20.0 & 23.0 \\
\hline New Zealand & & 17.2 & 23.2 & 17.6 & 18.1 & 18.4 \\
\hline Norway & 3.4 & 6.8 & 11.6 & 25.2 & 23.4 & 22.6 \\
\hline Poland & & 2.0 & 1.8 & 15.5 & 18.4 & 19.1 \\
\hline Portugal & 1.1 & 5.1 & 8.0 & 20.3 & 24.4 & 28.5 \\
\hline Russian Federation & & 8.2 & 7.9 & & 17.9 & 17.9 \\
\hline Slovak Republic & & 2.2 & 3.9 & 16.0 & 16.4 & 16.3 \\
\hline Slovenia & & 8.5 & 11.2 & 15.6 & 20.9 & 23.9 \\
\hline Spain & 0.7 & 4.9 & 14.5 & 23.4 & 24.6 & 24.9 \\
\hline Sweden & 5.6 & 11.3 & 14.8 & 27.6 & 26.8 & 28.1 \\
\hline Switzerland & 16.3 & 21.9 & 26.6 & 21.3 & 22.8 & 24.8 \\
\hline Turkey & & 1.9 & & 8.8 & 10.6 & 10.3 \\
\hline United Kingdom & 3.2 & 7.9 & 11.5 & 24.1 & 23.2 & 24.1 \\
\hline United States & 4.7 & 11.0 & 12.9 & 19.0 & 18.8 & 19.5 \\
\hline
\end{tabular}

Source: OECD (1999, 2003, 2010, 2011, 2013), OECD Population database and own calculations.

Notes: Stock of foreign born is in percentage of total population. 1992 is used instead of 1990 for Australia, 1996 for Canada, and 1995 for Hungary; 2001 is used instead of 2000 for Greece, Italy, Slovak Republic, Russian Federation while 2002 for Poland, Chile and Slovenia; 2011 is used instead of 2010 for Poland and 2004 for Slovak Republic. Old dependency ratio refers to 65+ over 15-64; the old dependency ratio for the Czech Republic is calculated from Eurostat data. 
Table 2: Selected studies of individual determinants of migration

\begin{tabular}{|c|c|c|c|c|}
\hline Study & Country & Age & Age Squared & $\begin{array}{l}\text { Age of Max. } \\
\text { Migr. Prob. }\end{array}$ \\
\hline \multicolumn{5}{|l|}{ International } \\
\hline $\begin{array}{l}\text { Massey and Brown } \\
\text { (2011) } \\
\text { Stark and Taylor } \\
\text { (1991) } \\
\text { Vadean and } \\
\text { Piracha (2009) }\end{array}$ & $\begin{array}{l}\text { From Mexico to } \\
\text { the US and Canada } \\
\text { From Mexico to } \\
\text { the US } \\
\text { From Albania }\end{array}$ & $\begin{array}{l}\text { US: } 0.072 \\
\text { Canada: n.s. } \\
\text { Logit coef: } \\
0.552 \\
\text { MNL, odds ratios: } \\
\text { Permanent: } 0.90 \\
\text { Return: } 0.94 \\
\text { Circular: } 0.91\end{array}$ & $\begin{array}{l}\text { US: }-0.001 \\
\text { Canada: n.s. } \\
\text { Logit coef: } \\
-0.009\end{array}$ & $\begin{array}{l}\text { around } 30 \text { years } \\
20-30 \text { years }\end{array}$ \\
\hline \multicolumn{5}{|l|}{ Interregional } \\
\hline $\begin{array}{l}\text { Bodvarsson et al } \\
\text { (2014) }\end{array}$ & China & $\begin{array}{l}\text { LPM: } \\
\text { Age 15-19: } \\
0.037 / 0.045 \\
\text { Age 19-30: } \\
0.005 / \mathrm{n} .5 . \\
\text { Age 30-65: - } \\
0.005 /-0.010\end{array}$ & & $15-19$ years \\
\hline $\begin{array}{l}\text { Liebig and Sousa- } \\
\text { Poza (2006) }\end{array}$ & Switzerland & $\begin{array}{l}\text { Cox prop. hazard } \\
\text { rate: } \\
-0.007 \text { / - } 0.009\end{array}$ & & \\
\hline Hunt (2006) & $\begin{array}{l}\text { East-West } \\
\text { Germany }\end{array}$ & $\begin{array}{l}\text { MNL, expon. coef, } \\
\text { emigrants: } \\
\text { Age 18-21: } 8.29 \\
\text { Age 22-25: } 6.56 \\
\text { Age 26-29: } 4.29 \\
\text { Age 30-35: } 1.96 \\
\text { Age 36-45: n.s. } \\
\text { (Ref: age 46-53) }\end{array}$ & & 18-21 years \\
\hline $\begin{array}{l}\text { Böheim and Taylor } \\
\text { (2002) }\end{array}$ & Great Britain & $\begin{array}{l}\text { Probit ME: } \\
\text { Age 16-22: } 0.028 \\
\text { Age 23-29: } 0.032 \\
\text { Age 40-49: }-0.033 \\
\text { Age 50+: -0.048 } \\
\text { (Ref: 30-39) }\end{array}$ & & 23-29 years \\
\hline Agesa (2001) & $\begin{array}{l}\text { Kenya: rural-to- } \\
\text { urban }\end{array}$ & 0.048 & & \\
\hline $\begin{array}{l}\text { Stark and Taylor } \\
\text { (1991) }\end{array}$ & Mexico & $\begin{array}{l}\text { Logit coef: } \\
0.348\end{array}$ & $\begin{array}{l}\text { Logit coef: } \\
-0.006\end{array}$ & 20-30 years \\
\hline $\begin{array}{l}\text { Hunt and Kau } \\
\text { (1985) }\end{array}$ & US & $\begin{array}{l}\text { Probit coef: } \\
-0.610\end{array}$ & & \\
\hline
\end{tabular}


Table 3: Age as a determinant of labor migration from 10 new EU member states

\begin{tabular}{lcc}
\hline & $(1)$ & $(2)$ \\
\hline Age 15-19 & 0.0010 & 0.0006 \\
& $(0.0007)$ & $(0.0007)$ \\
Age 20-29 & $0.0024^{* * *}$ & $0.0019^{* * *}$ \\
& $(0.0002)$ & $(0.0002)$ \\
Age 40-49 & $-0.0009^{* * *}$ & $-0.0010^{* * *}$ \\
& $(0.0002)$ & $(0.0002)$ \\
Age 50-59 & $-0.0030^{* * *}$ & $-0.0030^{* * *}$ \\
& $(0.0002)$ & $(0.0002)$ \\
Age 60-69 & $-0.0049^{* * *}$ & $-0.0048^{* * *}$ \\
& $(0.0002)$ & $(0.0002)$ \\
Age 70+ & $-0.0065^{* * *}$ & $-0.0064^{* * *}$ \\
& $(0.0001)$ & $(0.0001)$ \\
Observations & $1,113,447$ & $1,113,442$ \\
\hline
\end{tabular}

Notes: Marginal effects from probit regressions. Robust standard errors are in parentheses. * Significant at $10 \%$; ** significant at 5\%; *** significant at 1\%. The 10 new EU member states are: Bulgaria, Czech Republic, Estonia, Hungary, Latvia, Lithuania, Poland, Romania, Slovakia and Slovenia. Sample includes individuals older than 14 years old and excludes those in military service. Reference category is age 30-39. Other regressors include gender, marital status, number of children, education, year and country dummies in column (1), as well as labor market status one year before the survey in column (2). 
Table 4: Selected studies of demographic macro-determinants of migration

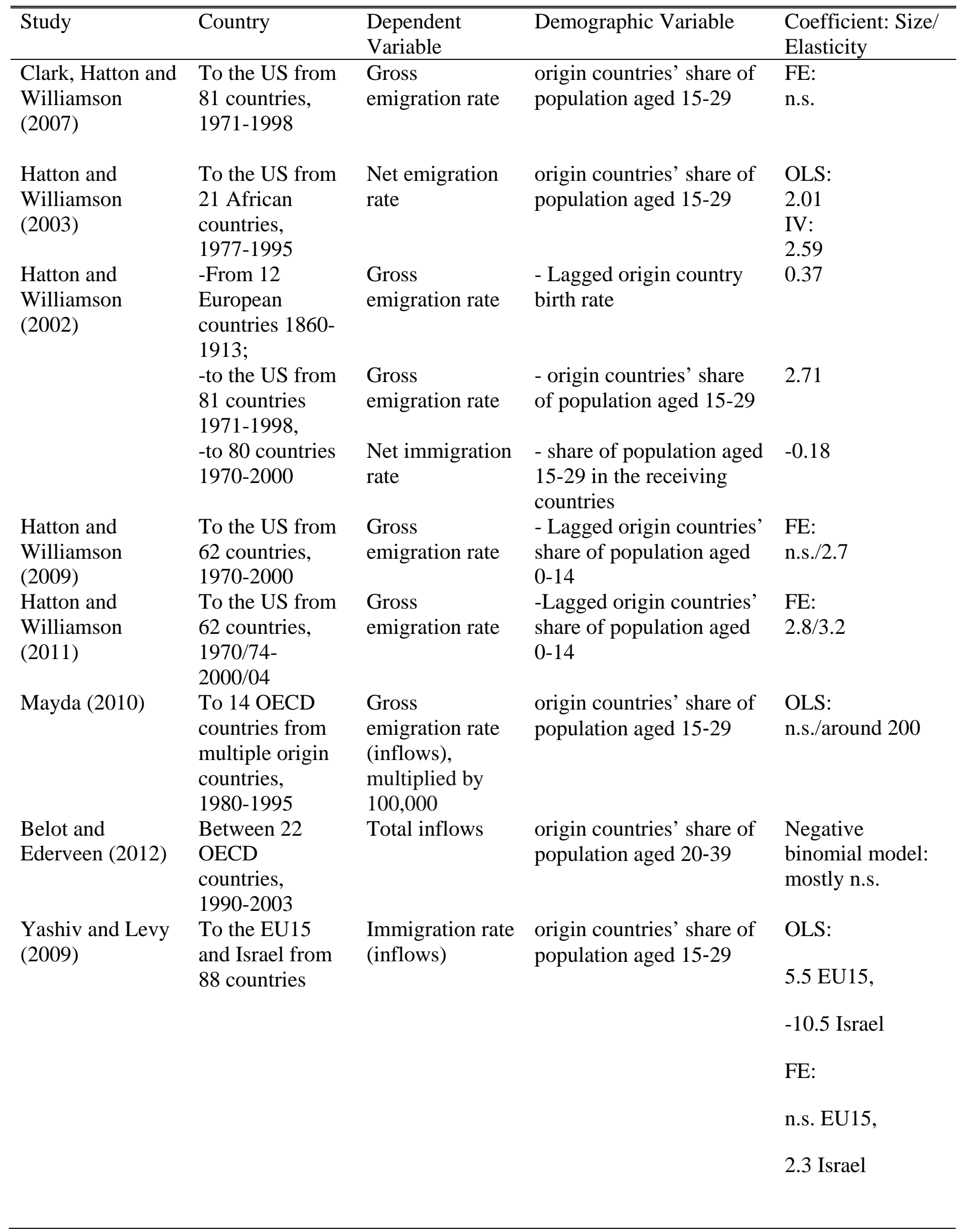




\begin{tabular}{|c|c|c|c|c|}
\hline $\begin{array}{l}\text { Bertochi and } \\
\text { Strozzi (2008) }\end{array}$ & $\begin{array}{l}14 \text { European } \\
\text { countries, } \\
1870-1910\end{array}$ & $\begin{array}{l}\text { Gross } \\
\text { immigration rate }\end{array}$ & $\begin{array}{l}\text { share of population aged } \\
15-29 \text { in country } i\end{array}$ & $\begin{array}{l}\text { OLS: } \\
-1.5 /-2.5 \\
\text { IV: } \\
-1.6 /-1.8\end{array}$ \\
\hline $\begin{array}{l}\text { Hanson and } \\
\text { McIntosh (2010) }\end{array}$ & $\begin{array}{l}\text { From Mexico to } \\
\text { the US, 1960- } \\
2000\end{array}$ & $\begin{array}{l}\text { Net migration } \\
\text { rate as } \\
\text { difference in the } \\
\text { size of birth } \\
\text { cohort between } \\
10 \text { years in } \\
\text { Mexican states }\end{array}$ & $\begin{array}{l}\text {-Size of a Mexican state } \\
\text { birth cohort relative to the } \\
\text { number of U.S. high } \\
\text { school dropouts in that } \\
\text { birth cohort }\end{array}$ & $\begin{array}{l}\text { OLS: } \\
0.030-0.049 \\
\text { IV: } \\
0.071-0.144\end{array}$ \\
\hline $\begin{array}{l}\text { Hanson and } \\
\text { McIntosh (2012) }\end{array}$ & $\begin{array}{l}\text { To US, Canada, } \\
\text { UK, Spain from } \\
25 \text { Latin } \\
\text { American } \\
\text { countries, 1980- } \\
2005\end{array}$ & $\begin{array}{l}\text { Net migration } \\
\text { rate as } \\
\text { difference in the } \\
\text { size of birth } \\
\text { cohort }\end{array}$ & $\begin{array}{l}\text {-Birth rates in the country } \\
\text { of origin's cohort (birth } \\
\text { cohort size) relative to } \\
\text { that of destination } \\
\text {-Age cohort dummies } \\
(16-22,23-34,35-40)\end{array}$ & $\begin{array}{l}\text { Rel. birth cohort } \\
\text { size: } \\
\text { US: } 0.355 \\
\text { UK: - } 0.450 \\
\text { Canada, Spain: } \\
\text { n.s. } \\
\text { Pooled: } 0.120 \\
\text { Age cohorts: } \\
\text { highest emigr. at } \\
\text { ages 23-34 }\end{array}$ \\
\hline
\end{tabular}


Table 5: Young cohort size as a determinant of migration to Germany, 2000-2011

\begin{tabular}{|c|c|c|c|c|c|c|}
\hline \multirow[b]{3}{*}{$\begin{array}{l}\text { Share of } \\
\text { population } \\
\text { aged } 15-29\end{array}$} & \multicolumn{2}{|c|}{ EU28 } & \multicolumn{2}{|c|}{$\begin{array}{c}\text { US, Canada, Japan, Israel, } \\
\text { Australia, New Zealand, } \\
\text { EEA }\end{array}$} & \multicolumn{2}{|c|}{ Other countries } \\
\hline & Pre-2008 & Post-2008 & Pre-2008 & Post-2008 & Pre-2008 & Post-2008 \\
\hline & $\begin{array}{c}17.57 * * * \\
(6.417)\end{array}$ & $\begin{array}{c}-20.82 * * * \\
(6.421)\end{array}$ & $\begin{array}{l}11.18 * * \\
(3.500)\end{array}$ & $\begin{array}{c}-11.75^{*} \\
(6.251)\end{array}$ & $\begin{array}{c}-2.36 \\
(4.913)\end{array}$ & $\begin{array}{c}-5.08 \\
(6.651)\end{array}$ \\
\hline Observations & 206 & 108 & 72 & 36 & 354 & 174 \\
\hline \multicolumn{7}{|c|}{$\begin{array}{l}\text { Notes: Estimates from panel fixed-effects models are reported. Robust standard errors are in parentheses. * Significant } \\
\text { at } 10 \% \text {; ** significant at } 5 \% \text {; *** significant at } 1 \% \text {. Dependent variable is log gross migration to Germany, divided by } \\
\text { the source country population. Other regressors include source country GDP per capita and its square, unemployment } \\
\text { rate and year dummies. Immigration flows are from the OECD International Migration database, GDP per capita, PPP } \\
\text { (constant } 2005 \text { international dollars), unemployment rate and population are from the World Bank World Development } \\
\text { Indicators database. }\end{array}$} \\
\hline
\end{tabular}

Table 6: Health of natives and immigrants in Germany

\begin{tabular}{lcccc}
\hline \hline & Natives & \multicolumn{2}{c}{ YSM 0-10 } & \multicolumn{2}{c}{ YSM 11-20 } & YSM >20 \\
\cline { 2 - 4 } Age: & \multicolumn{4}{c}{ Bad or poor health } \\
$15-30$ & 0.055 & 0.034 & 0.061 & 0.028 \\
$31-40$ & 0.093 & 0.072 & 0.070 & 0.068 \\
$41-60$ & 0.180 & 0.314 & 0.227 & 0.237 \\
$>60$ & 0.282 & $0.438^{*}$ & 0.383 & 0.308 \\
& & \multicolumn{2}{c}{ Diagnosed severe illness } \\
$15-30$ & 0.069 & 0.031 & 0.000 & 0.070 \\
$31-40$ & 0.138 & 0.145 & 0.108 & 0.120 \\
$41-60$ & 0.344 & 0.353 & 0.227 & 0.313 \\
$>60$ & 0.635 & $0.471^{*}$ & 0.524 & 0.578 \\
\hline
\end{tabular}

Notes: GSOEP, 2011 wave. Sample means are reported. "YSM" stands for years since migration. * The number of observations within this specific group is less than 30. "Bad or Poor Health" refers to the self-reported health status, and is equal to 1 if an individual describes his or her current health as "bad" or "poor". "Diagnosed illness" is equal to 1 if a doctor has ever diagnosed an individual to have at least one of the following illnesses: stroke, blood pressure problems, diabetes, cancer, psychiatric problems, arthritis, or a heart condition. 
Figure 1: Population change in 28 EU countries, 1960-2010

\section{EU 28}

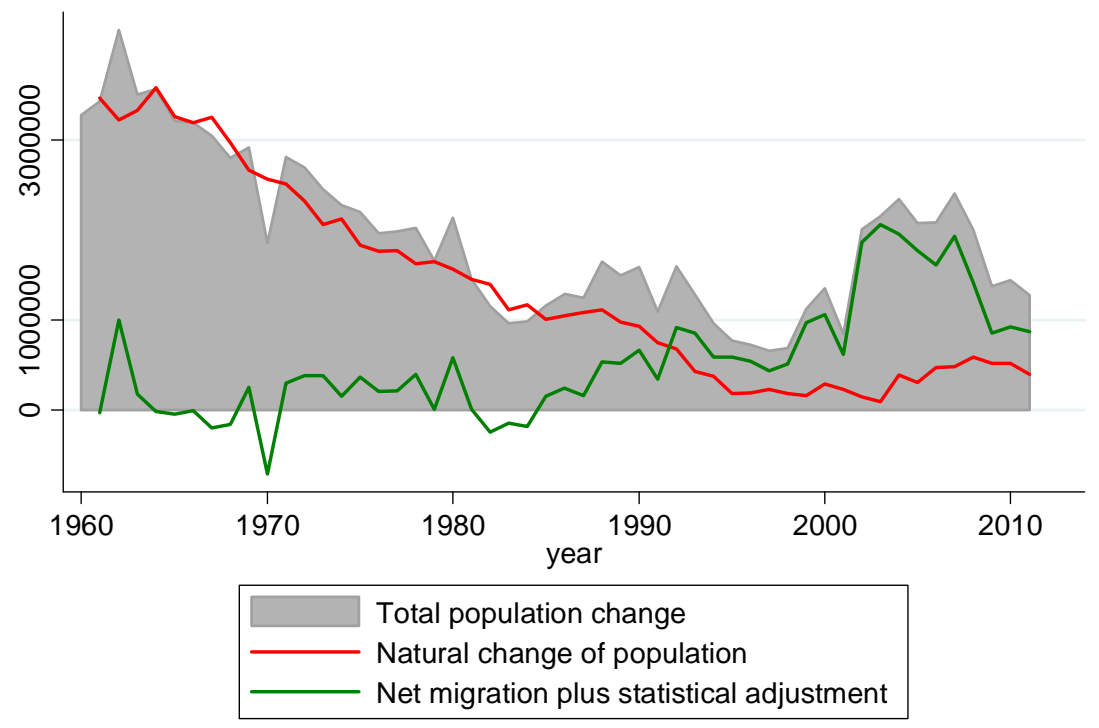

Source: United Nations online database. 
Figure 2: Migrants across age

a) International migrants as a percentage of the population by age, 2013

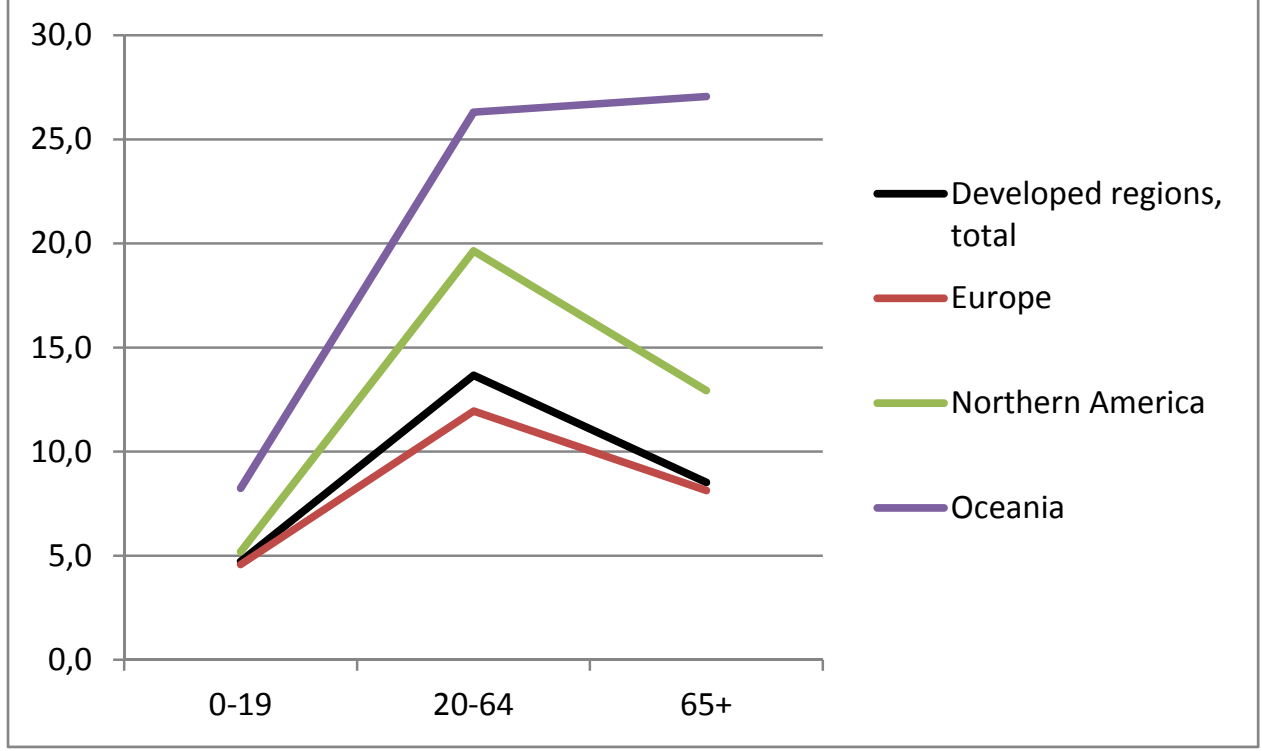

b) International migrants as a percentage of the population by age for selected countries, 2013

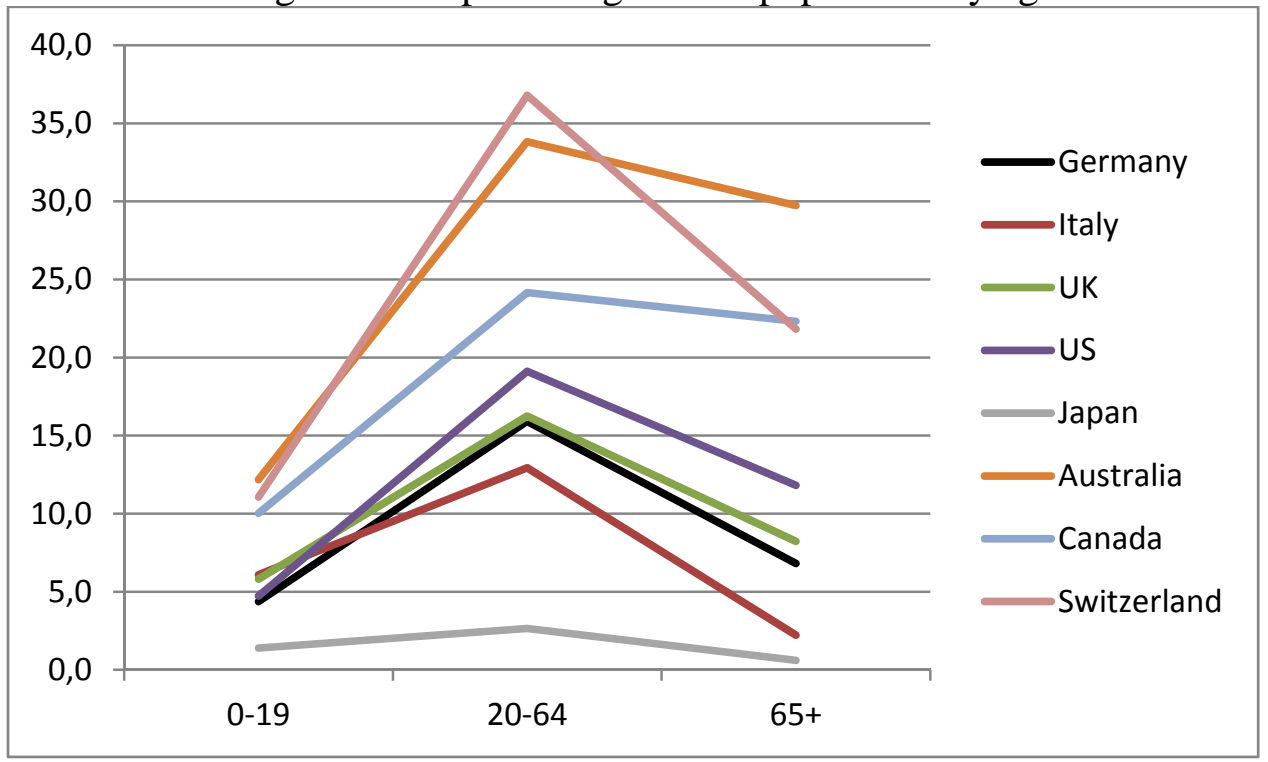

Source: United Nations, Department of Economic and Social Affairs, Population Division (2013). The Age and Sex of Migrants 2013 Wallchart (United Nations publication, Sales No. 12.XIII.2). 
Figure 3: Immigrant distribution by age of last migration to Germany, Italy and Spain

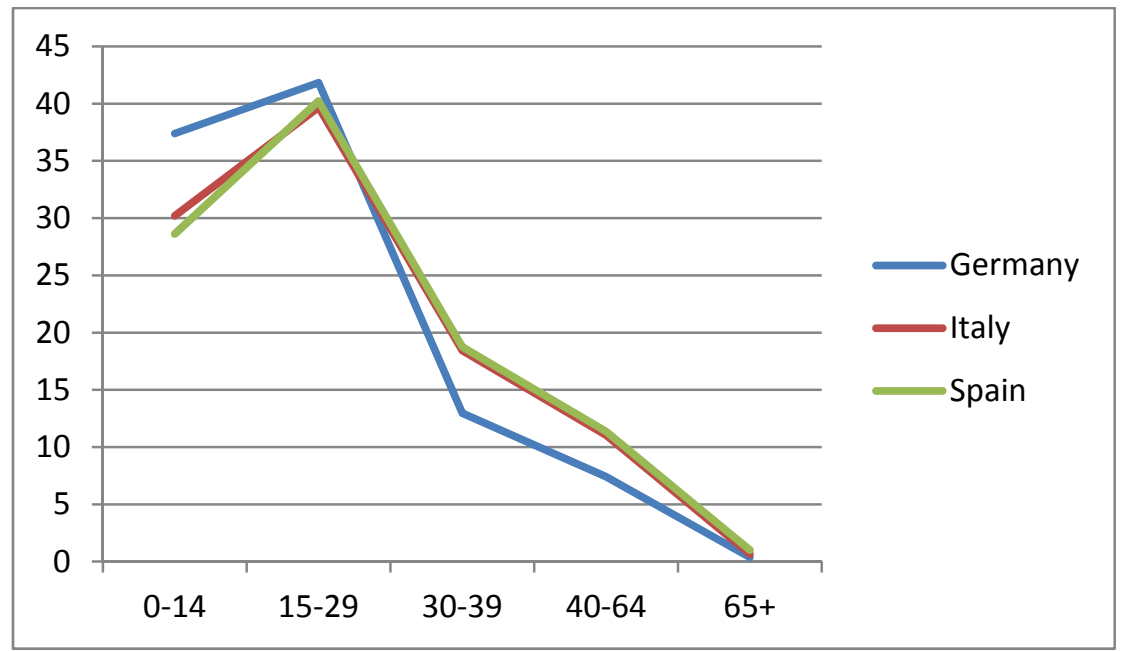

Source: Authors' calculations from the EU Labour Force Survey 2011 data.

Notes: Age of last migration refers to the age at which the person last established his or her usual residence in the country; only non-nationals are included; simple (unweighted) frequencies.

Figure 4: Attitudes towards immigrants in Europe, 2009

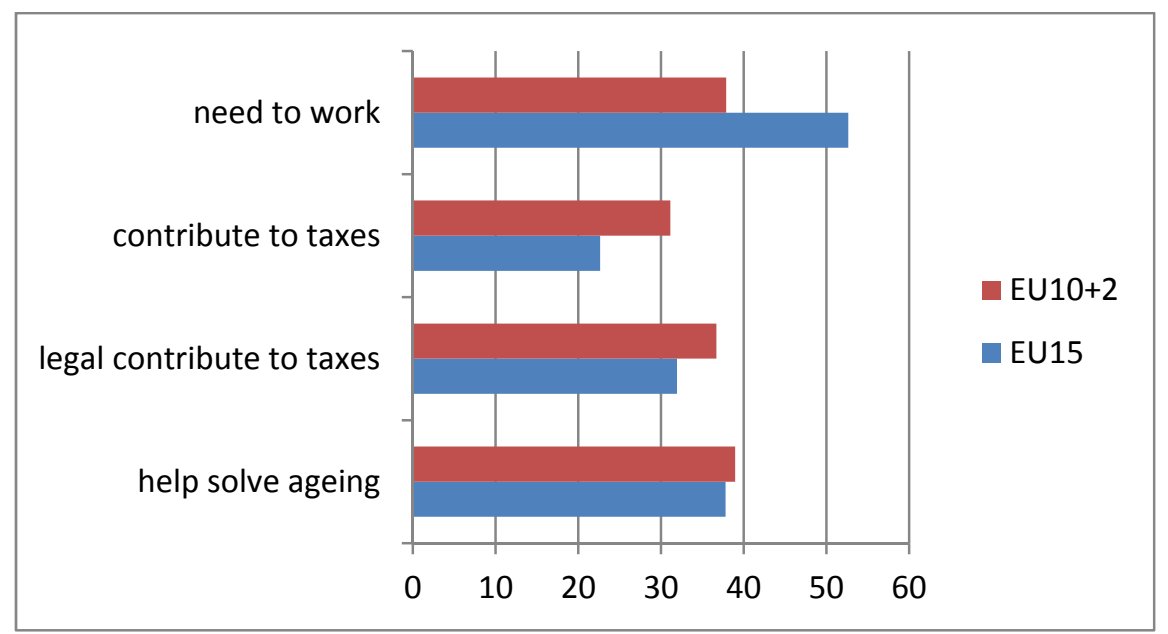

Source: Authors' calculations from the Eurobarometer 71.3 dataset.

Notes: Proportion of respondents replying "tend to agree" to the corresponding questions; weighted by sample weights provided for the EU15 and new EU members (EU10+2); only includes natives. 
Figure 5: Individual opinions about sustainability of the future welfare system and immigration alleviating the aging problem in Europe, 2009

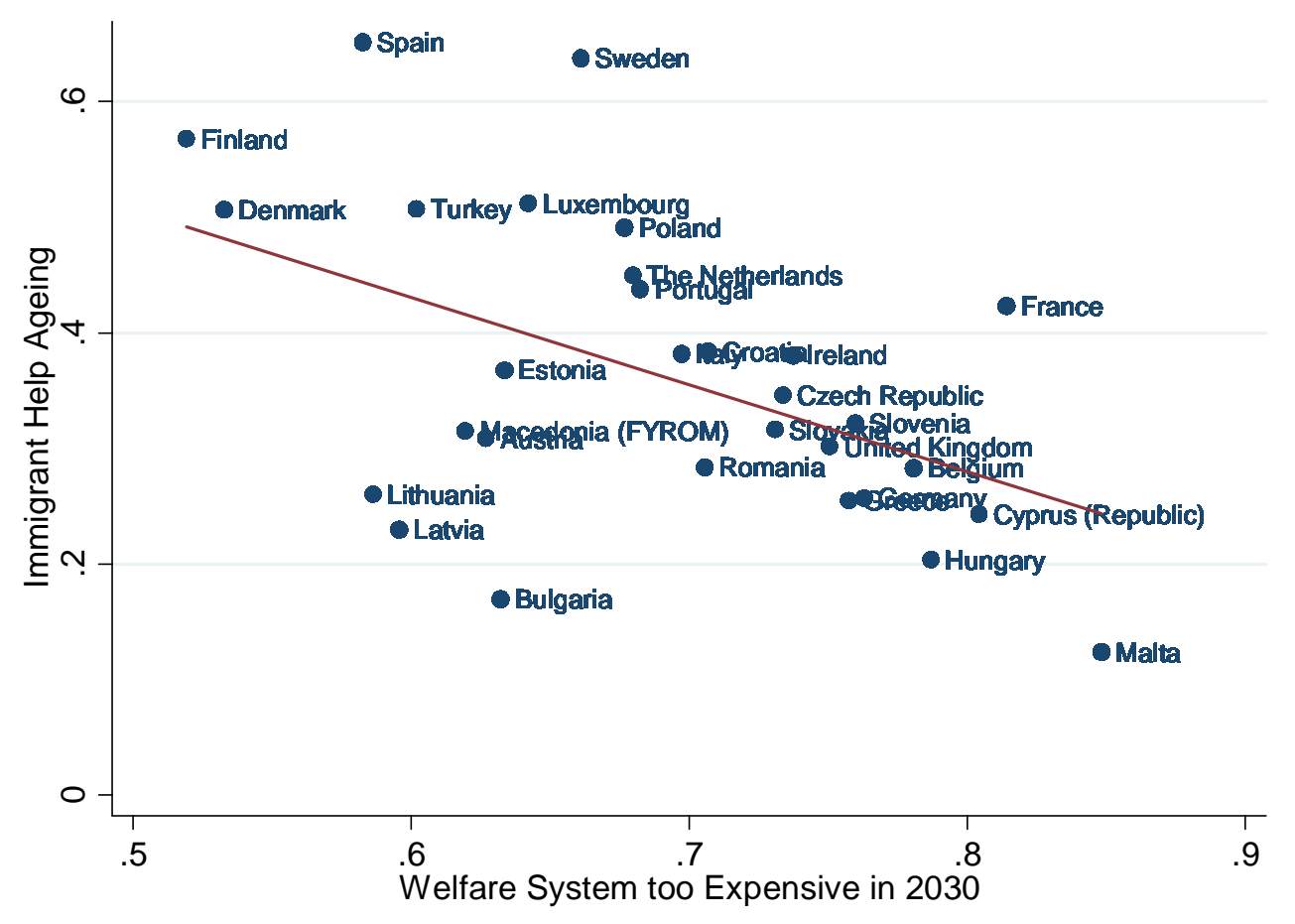

Source: Authors’ calculations from the Eurobarometer 71.3 dataset.

Figure 6: Individual opinions about confidence in own pensions and immigration alleviating the European aging problem, 2009

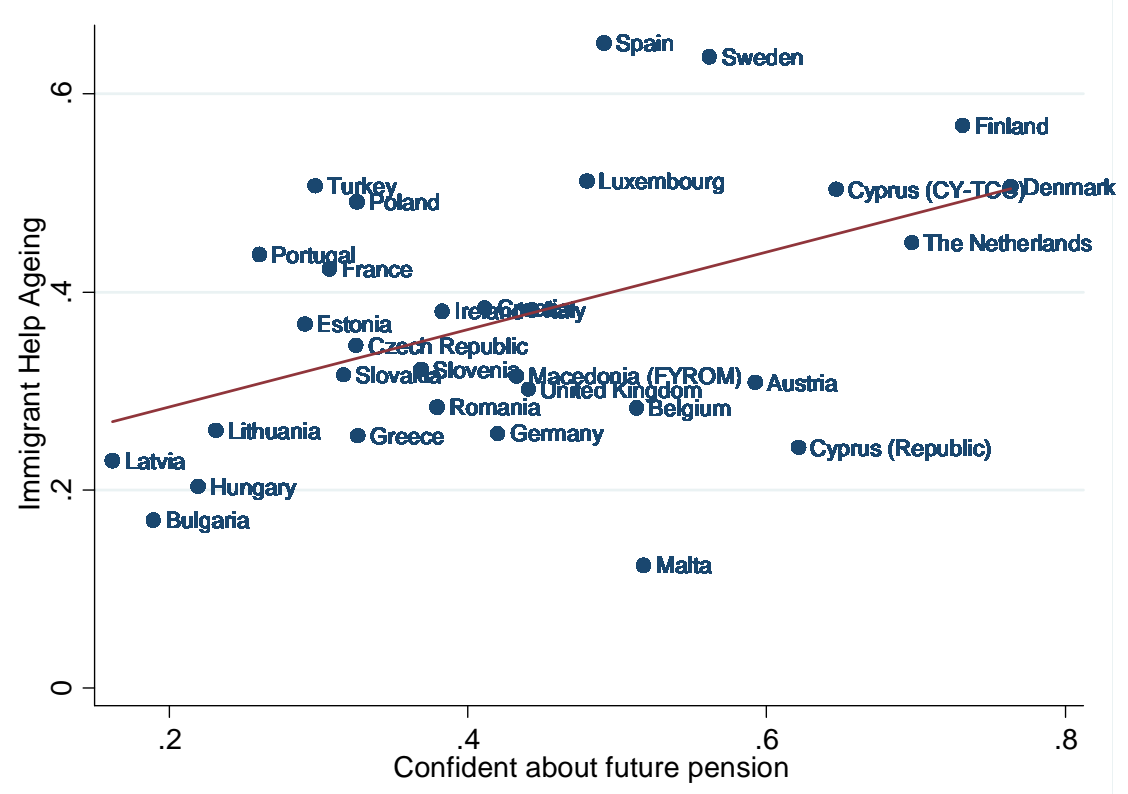

Source: Authors’ calculations from the Eurobarometer 71.3 dataset. 